\title{
Enhanced IFN $\alpha$ Signaling Promotes Ligand-Independent Activation of ER $\alpha$ to Promote Aromatase Inhibitor Resistance in Breast Cancer
}

\author{
Taylor E. Escher ${ }^{1}$, Prasad Dandawate ${ }^{1,2}$, Afreen Sayed ${ }^{1}$, Christy R. Hagan ${ }^{1,2,3}$ (D), Shrikant Anant ${ }^{1,2}(\mathbb{D}$ \\ and Joan Lewis-Wambi ${ }^{1,2, *}$
}

1 Department of Cancer Biology, University of Kansas Medical Center, 3901 Rainbow Boulevard, Kansas City, KS 66160, USA; tescher@kumc.edu (T.E.E.); pdandawate@kumc.edu (P.D.); asayed@kumc.edu (A.S.); chagan@kumc.edu (C.R.H.); sanant@kumc.edu (S.A.)

2 The University of Kansas Cancer Center, 3901 Rainbow Boulevard, Kansas City, KS 66160, USA

3 Department of Biochemistry and Molecular Biology, University of Kansas Medical Center, 3901 Rainbow Boulevard, Kansas City, KS 66160, USA

* Correspondence: jlewis-wambi@kumc.edu; Tel.: +913-588-4739; Fax: +913-588-4701

check for updates

Citation: Escher, T.E.; Dandawate, P.; Sayed, A.; Hagan, C.R.; Anant, S.; Lewis-Wambi, J. Enhanced IFN $\alpha$ Signaling Promotes

Ligand-Independent Activation of $\mathrm{ER} \alpha$ to Promote Aromatase Inhibitor Resistance in Breast Cancer. Cancers 2021, 13, 5130. https://doi.org/ $10.3390 /$ cancers 13205130

Academic Editor: Takayuki Ueno

Received: 1 September 2021

Accepted: 11 October 2021

Published: 13 October 2021

Publisher's Note: MDPI stays neutral with regard to jurisdictional claims in published maps and institutional affiliations.

Copyright: (c) 2021 by the authors. Licensee MDPI, Basel, Switzerland. This article is an open access article distributed under the terms and conditions of the Creative Commons Attribution (CC BY) license (https:/ / creativecommons.org/licenses/by/ $4.0 /)$.
Simple Summary: Interferon alpha (IFN $\alpha$ ) signaling is highly upregulated in ER+ breast cancers that become resistant to estrogen deprivation therapy. This study uncovers how enhanced (IFN $\alpha$ )/JAKSTAT signaling directly influences estrogen receptor $(\mathrm{ER} \alpha)$ activation in the absence of estrogen. We found that inhibiting IFN $\alpha$ signaling downregulates expression and activation of ER $\alpha$. In addition, STAT1 and ER $\alpha$ directly interact and regulate a key interferon-stimulated gene, IFITM1, in AIresistant breast cancer cells. We demonstrate that crosstalk occurs between IFN $\alpha$ and ER $\alpha$ pathways, which contributes to aggression and survival of AI-resistant breast cancer, thus representing a novel mechanism of acquired AI resistance.

Abstract: Aromatase inhibitors (AIs) reduce estrogen levels up to $98 \%$ as the standard practice to treat postmenopausal women with estrogen receptor-positive $(\mathrm{ER}+)$ breast cancer. However, approximately $30 \%$ of ER+ breast cancers develop resistance to treatment. Enhanced interferon-alpha $(\mathrm{IFN} \alpha)$ signaling is upregulated in breast cancers resistant to AIs, which drives expression of a key regulator of survival, interferon-induced transmembrane protein 1 (IFITM1). However, how upregulated IFN $\alpha$ signaling mediates AI resistance is unknown. In this study, we utilized MCF-7:5C cells, a breast cancer cell model of AI resistance, and demonstrate that these cells exhibit enhanced IFN $\alpha$ signaling and ligand-independent activation of the estrogen receptor (ER $\alpha)$. Experiments demonstrated that STAT1, the mediator of intracellular signaling for IFN $\alpha$, can interact directly with ER $\alpha$. Notably, inhibition of IFN $\alpha$ signaling significantly reduced ER $\alpha$ protein expression and ER-regulated genes. In addition, loss of ER $\alpha$ suppressed IFITM1 expression, which was associated with cell death. Notably, chromatin immunoprecipitation experiments validated that both ER $\alpha$ and STAT1 associate with ERE sequences in the IFITM1 promoter. Overall, hyperactivation of IFN $\alpha$ signaling enhances ligand-independent activation of $\mathrm{ER} \alpha$, which promotes ER-regulated, and interferon stimulated gene expression to promote survival in AI-resistant breast cancer cells.

Keywords: breast cancer; aromatase inhibitor; estrogen deprivation; AI resistance; estrogen receptor; interferon alpha; interferon-stimulated genes; IFITM1; STAT1

\section{Introduction}

Breast cancer is the most frequently diagnosed cancer among women in the United States (U.S.) and the second highest cause of death. It is estimated that in 2021, approximately 281,550 U.S. women will receive a diagnosis of invasive breast cancer and 43,000 women will die from the disease [1-4]. The most frequently diagnosed subtype of 
breast cancer is ER+ (estrogen receptor and/or progesterone receptor positive) accounting for approximately $70 \%$ of diagnoses $[5,6]$. Because estrogen promotes cancer progression, the standard treatment for ER+ breast cancer blocks ER $\alpha$ signaling. Aromatase inhibitors (AIs), which decrease estrogen production by 90-98\%, are now the standard of care for postmenopausal ER+ breast cancer [7-10]. Despite the efficacy of AIs, approximately $30 \%$ of patients develop recurrent disease within 10 years, demonstrating resistance to AIs in tumors. To treat these patients, it is critical to understand the molecular mechanisms of acquired AI resistance.

Our lab has previously identified that the interferon alpha (IFN $\alpha$ )/JAK-STAT signaling pathway is a mechanism of AI resistance [11]. Interferons (IFNs) are cytokines secreted by the body to increase antiviral responses in cells, but they also influence pro-survival signaling mechanisms. Picomolar concentrations of IFNs autonomously secreted by cancer cells for an extended duration induce expression of ISGs important in cancer progression and therapy resistance [12,13]. For example, expression of ISGs including PLSCR1 and IFITM1/3 promotes tumor progression and invasion in clinical samples and cancer cell lines [14-16]. Mechanistically, IFN $\alpha$ activates JAK/STAT signaling through binding to the IFN $\alpha$ receptor 2 (IFNAR2). P-STAT1, P-STAT2, and interferon regulatory factor 9 (IRF9) bind to interferon-stimulated response elements (ISREs) to transcribe ISGs. Indeed, hyperactivated IFN $\alpha / \mathrm{JAK} / \mathrm{STAT}$ signaling is pro-tumorigenic and confers resistance to treatment; however, the exact molecular mechanism has yet to be elucidated $[17,18]$.

Recently, our lab identified overexpression of multiple ISGs in AI-resistant breast cancer including interferon-induced transmembrane protein 1 (IFITM1), which is critical for regulating survival of acquired AI-resistant breast cancer cells [11,19,20]. IFITM1 contributes to protein complexes involved in cell adhesion, germ cell homing, and viral infection [21]. IFITM1 resides on plasma membranes and can interact with multiple proteins including RAB5, LAMP1, CD63, CD19, CD21 and CD81 [22,23], which can regulate EMT, cell adhesion, angiogenesis, invasion, and metastasis [24]. Other studies have validated the importance of IFITM1 and shown correlation with poor overall and recurrence-free survival in multiple tumor types. Its overexpression in gastric, esophageal, colorectal, cervical, ovarian, brain, and breast cancer promotes proliferation, migration, invasion, and metastasis [25-33].

Traditionally, the estrogen receptor functions as a classic steroid hormone receptor. Estrogen binds to ER $\alpha$, allowing it to act as a transcription factor [34]. ER $\alpha$ can also signal through a ligand-independent (or estrogen-independent) mechanism. Through tethered protein-protein interactions with other transcription factors (FOXA1 SP1, AP1, Pitx1, Runx1, SF-1, SRCs, NFkB, and C/EBP) and rapid phosphorylation cascades through the serine 167 and 118 residues, ER $\alpha$ can regulate signaling non-canonically [34-37]. Many cell signaling proteins including GPCRs, Src, PI3K, EGFR, HER2, IGF-1, and MAPK can influence the ligand-independent activation of $\operatorname{ER} \alpha[34,38]$. This ligand-independent signaling allows breast cancers to become resistant to AIs. We hypothesize that long-term estrogen deprivation enhances IFN $\alpha$ signaling in AI-resistant breast cancer cells, which drives ligand-independent activation of $\mathrm{ER} \alpha$ and promotes AI resistance.

In this study, we investigated whether $\mathrm{ER} \alpha$ is directly regulated by IFN $\alpha$ signaling, representing a potential mechanism by which ER+ breast cancers develop resistance to estrogen deprivation therapy. We discovered that AI-resistant MCF-7:5C breast cancer cells constitutively express enhanced ER $\alpha$ (total and phosphorylated) expression as well as ER-regulated genes compared to AI-sensitive MCF-7 and T47D cells and that blockade of IFN $\alpha$ signaling or knockdown of STAT1/2 markedly reduces ER $\alpha$ expression and ERregulated genes in these cells. Additionally, we found that ER $\alpha$ and STAT1 physically interact in MCF-7:5C cells through protein docking studies, proximity ligation assay, and immunoprecipitation. Notably, chromatin immunoprecipitation studies show that STAT1 and $\mathrm{ER} \alpha$ associate with IFITM1 promoter to drive its expression in AI-resistant MCF-7:5C cells. Surprisingly, ligand treatment (through $\mathrm{E}_{2}$ ) inhibits IFITM1 promoter occupation and expression and induces cell death. Together, these findings demonstrate a novel 
crosstalk between IFN $\alpha$ signaling and ligand-independent activation of ER $\alpha$ in promoting AI resistance in breast cancer.

\section{Materials and Methods}

\subsection{Cell Lines}

The MCF-7 cell line was obtained from Dr. V. Craig Jordan (University of Texas MD Anderson Cancer Center, Houston, TX, USA) and the MCF-7:5C was cloned from parental MCF-7 cells following long-term (>12 months) culture in estrogen-free medium [39]. The T-47DA:18 cell line (hereafter referred to as T47D) was derived from T47D cells originally obtained from ATCC (Rockville, MD, USA) [40,41]. All cell lines were cultured as previously described [42] at $37{ }^{\circ} \mathrm{C}$ under $5 \% \mathrm{CO}_{2}$.

\subsection{Small Interfering RNA (siRNA) Transfections}

T47D, MCF-7, and MCF-7:5C cells $\left(1 \times 10^{5}\right)$ were transiently transfected with siRNAs for ER $\alpha$ (Santa Cruz Biotechnology, Dallas, TX, USA, Cat\#sc-29305), STAT1 (Santa Cruz Biotechnology, Cat\#sc-44123), and STAT2 (Santa Cruz Biotechnology, Cat\#sc-29492) or a scrambled negative control (Santa Cruz Biotechnology, Cat\#sc-37007). The ER $\alpha$, STAT1, STAT2 and control siRNAs were pools of three target-specific 20 to $25 \mathrm{nt}$ siRNAs as previously described [42].

\subsection{Cell Counting for Proliferation}

T47D, MCF-7, and MCF-7:5C $\left(1 \times 10^{4}\right)$ cells were assayed for viability and proliferation in 24-well plates in triplicate in estrogen-free medium. After $72 \mathrm{~h}$ transfection, cells were counted by Trypan blue (Sigma, St. Louis, MO, USA, Cat\#T8154) exclusion direct cell counts.

\subsection{Western Blotting}

Following $48 \mathrm{~h}$ treatment as indicated with $1 \mathrm{nmol} \mathrm{E} 2$ (Sigma, Cat\#E8875), $48 \mathrm{~h}$ treatment with siER (Santa Cruz Biotechnology, Cat\#SC-29305), 24 h treatment with $10 \mu \mathrm{mol}$ IFNAR NAb (Millipore, Burlington, MA, USA, MAB1155), 48 h treatment with $1 \mu$ mol Ruxolitinib/Jakafi ${ }^{\mathrm{TM}}$ (Rux) [43] as indicated (Cayman Chemical, Ann Arbor, MI, USA, Cat\#11609), cells were harvested, underwent protein assay, separated by SDS-PAGE, transferred and blocked. After primary and secondary antibody incubation, bands were detected and exposed to film, as previously described [42]. Target proteins were detected using primary antibodies: anti-p-ER $\alpha$ S167 (Cell Signaling, Danvers, MA, USA, Cat\#64508S), antip-ER $\alpha$ S118 (Cell Signaling, Cat\#2511S), anti-ER $\alpha$ (Cell Signaling, Cat\#8644S), anti-p-STAT1 (Santa Cruz Biotechnology, Cat\#SC-8394), anti-p-STAT2 (Cell Signaling, Cat\#88410S), antiSTAT1 (Santa Cruz Biotechnology, Dallas, TX, USA, Cat\#SC-464), anti-STAT2 (Santa Cruz Biotechnology, Cat\#SC-514193), anti-IFITM1 (Santa Cruz Biotechnology, Cat\#SC-374026) or anti- $\beta$-actin (Cell Signaling, Cat\#3700S). Western blotting of proteins is available in Supplementary Materials.

\subsection{RNA Isolation and Real-Time PCR}

Following $48 \mathrm{~h}$ treatment or transfection, cells were harvested, total RNA was isolated, cDNA was synthesized, and RT-PCR was conducted. (Primers are outlined in Table S1 [42]). Relative mRNA expression level was determined as the ratio of the signal intensity to that of PUM1 using the formula: $2^{-\Delta C T}$. When cells were treated, fold change in gene expression was normalized to PUM1 and then compared to the untreated value for that cell line using the formula: $2^{-\Delta \Delta C T}$. 


\subsection{Immunofluorescent (IF) Staining}

Following fixing and permeabilization, cells were stained using primary antibodies against anti-IFITM1 (Santa Cruz Biotechnology, Cat\#SC-374026) and anti-ER $\alpha$ (Santa Cruz Biotechnology, Cat\#SC-544) followed by secondary antibodies, and mounted as previously described [42]. Images were collected on a Leica TCS SPE confocal microscope and analyzed using the Leica LAS AF Lite software (Leica Biosystems, Nussloch, Germany).

\subsection{Proximity Ligation Assay}

Fixed cells were washed with PBS, permeabilized with $0.1 \%$ Triton- $X$ in $1 \times$ PBS for $15 \mathrm{~min}$, and incubated with Duolink ${ }^{\circledR}$ blocking solution. For the remainder of the processing the Duolink ${ }^{\circledR}$ PLA Fluorescence (Sigma Aldrich, St. Louis, MO, USA, \#DUO92001) was used per the manufacturer's instructions. Antibodies used were ER $\alpha$ rabbit (Cell Signaling Technologies, \#8644S,) and STAT1 mouse (1:200, Santa Cruz: sc-464).

\subsection{Dual Luciferase Reporter Assays}

For promoter assays, $0.8 \mu \mathrm{g}$ of plasmid DNA and pRL CMV Renilla vector were used [44]. For analysis of IFITM1 promoter activity, the pGL3 plasmid with the first 750 nucleotides of the IFITM1 promoter inserted (pGL3-IFITM1 [-750/-1]) was used [44]. The pGL3-Basic-IRES was a kind gift from Joshua Mendell (Addgene, Watertown, MA, USA, Cat\#64784) [45]. Analysis of ISRE and ERE promoter activity was previously described [42].

\subsection{TUNEL Staining}

After $72 \mathrm{~h}$ transfection, TUNEL staining was conducted using the Click-iT Plus TUNEL Assay Kit (Invitrogen, Waltham, MA, USA, Cat\#C10618) following the manufacturer's instructions. The average TUNEL intensity was quantified using the red color channel on Image J software for a minimum of three images.

\subsection{Co-Immunoprecipitation (Co-IP)}

Cell lysates were collected incubated overnight at $4{ }^{\circ} \mathrm{C}$ with $2 \mu \mathrm{g}$ appropriate antibody or control IgG. 50:50 Protein A/G coated magnetic beads (Invitrogen, Cat\#10001D/Cat\#10003D) were then added for the final $1 \mathrm{~h}$ of incubation time. Immune complexes were washed three times with PBS, resuspended in Laemmli sample buffer (Invitrogen, Cat\#NP0007), boiled for $5 \mathrm{~min}$, and subjected to Western blotting analysis.

\subsection{In Silico Docking Analysis}

X-ray crystal structures of STAT1 (1YVL) and ER $\alpha$ (1A52) were downloaded from the protein data bank (PDB). These PDB files were prepared for docking analysis by removing ligands, water molecules and extra chains of amino acids that may interfere with the protein-protein interactions. Chain A was selected for both proteins which were further energy minimized to ensure the best folding of each protein and polar hydrogens and Kollman Charges were added using MGL tools. The final prepared protein structures were uploaded to the GRAMM-X Protein-protein Docking Web Server v.1.2.0 (http:/ / vakser. compbio.ku.edu/resources/gramm/grammx/, accessed on 8 February 2021) to check for protein-protein interactions $[46,47]$. The final output file was analyzed using the PYMOL program to isolate the interacting amino acids and bond lengths [48].

\subsection{Chromatin Immunoprecipitation (ChIP) Assay}

ChIP was performed after sonication using the ChIP-IT Express Kit (Active Motif, Carlsbad, CA, USA, Cat\#53008) according to the manufacturer's instructions. Lysates were immunoprecipitated (IP) overnight $(18 \mathrm{~h})$ with the following antibodies: anti-STAT1 (Cell Signaling, Cat\#9172S), anti-ER $\alpha$ (Cell Signaling, Cat\#8644S) or an equal amount of rabbit IgG (Santa Cruz Biotechnology, Cat\#SC-2027). Resulting DNA was analyzed using qPCR and run on a DNA gel. Data are represented as a percentage of input DNA. 


\section{Results}

3.1. ER $\alpha$ and ER-Regulated Genes Are Upregulated in Aromatase Inhibitor-Resistant Breast Cancer Cells

The estrogen-independent MCF-7:5C clone was derived from MCF-7 cells after longterm estrogen deprivation [39,49]. MCF-7:5C cells maintain wild-type ER $\alpha$ but lose PR expression and exhibit estrogen $\left(\mathrm{E}_{2}\right)$-induced cell death $[50,51]$. To better understand ER $\alpha$ function in AI-resistant MCF-7:5C cells, we measured total and phosphorylated ER $\alpha$ expression in these cells compared to AI-sensitive MCF-7 and T47D breast cancer cells. We found that AI-resistant MCF-7:5C cells expressed markedly elevated levels of total and phosphorylated (S167 and S118) ER $\alpha$ compared to MCF-7 and T47D cells and that ER $\alpha$ was primarily localized in the nucleus in MCF-7:5C cells, thus indicating a constitutively activated state (Figure 1A,B). Next, we examined the mRNA expression levels of five ER-regulated genes, including cyclin D1 (CCND1), c-Myc, Cathepsin D (CTSD), pS2, and FOXA1. As shown in Figure 1C, all the ER-regulated genes were highly upregulated in AI-resistant MCF-7:5C cells compared to MCF-7 and T47D cells, despite these cells being grown in estrogen-free conditions (Figure 1C). Finally, we assessed the mRNA expression of several well-known ER-coregulatory proteins including SP1, SRC-1, SRC-3, CBP, p300, GATA3, and CITED1 in MCF-7, T47D, and MCF-7:5C cells (Figure 1D). Surprisingly, we found that T47D cells had the highest expression of ER-coregulatory proteins, whereas MCF-7:5C cells had the lowest level compared to MCF-7 cells (Figure 1D).

\subsection{Loss of ERa Expression Induces Apoptosis Most Prominently in Aromatase Inhibitor-Resistant Breast Cancer Cells}

To test whether loss of ER $\alpha$ expression significantly impacts the phenotype of MCF7:5C, MCF-7, and T47D cells, we used siRNA to inhibit its expression. Figure 2 shows that loss of ER $\alpha$ markedly reduced the growth of AI-resistant MCF-7:5C cells compared to MCF7 and T47D cells and TUNEL staining confirmed that the decrease in growth was due to apoptosis, which was most pronounced in MCF-7:5C cells (Figure 2A,B). Immunoblotting analysis verified that $\mathrm{ER} \alpha$ inhibition increased PARP cleavage primarily in MCF-7:5C cells (Figure 2C). Lastly, we observed that in all three cell lines, knockdown of ER $\alpha$ significantly reduced the expression of ER-regulated genes; however, the effect was most pronounced in AI-resistant MCF-7:5C cells, which expressed the highest basal level of ER-regulated genes (Figure 2D, left panel) compared to MCF-7 (Figure 2D, right panel) and T47D cells (Figure 2D, bottom panel).

 Breast Cancer Cells}

Previously, we demonstrated the enhanced IFN $\alpha$ signaling in AI-resistant MCF-7:5C cells [11,26]; hence, we investigated the consequence of enhanced IFN $\alpha$ signaling on ER $\alpha$ function and its transcriptional activation. We first measured the expression of multiple interferon-stimulated genes (ISGs) including IFN $\alpha$, IFN $\beta$, IFIT1, IRF9, OAS1, STAT1, STAT2, PLSCR1, and IFITM1 and found that they were markedly elevated in AI-resistant MCF-7:5C cells but not expressed in MCF-7 cells (Figure 3A). Next, we determined whether enhanced IFN $\alpha$ signaling alters ER $\alpha$ expression and function by blocking the IFN $\alpha$ signaling pathway using an IFNAR neutralizing antibody (IFNAR NAb) and a JAK1 inhibitor, Ruxolitinib (Rux) (Figure 3B-D). Blockade of IFN $\alpha$ signaling significantly reduced total ER $\alpha, \mathrm{p}-\mathrm{ER} \alpha$ S167 levels, p-STAT1/p-STAT2, and IFITM1 expression (Figure 3B) in AI-resistant MCF7:5C cells. The expression of our selected ER-regulated genes (CCND1, pS2, CTSD, FOXA1, and c-Myc) was markedly reduced in these cells with no significant effect in MCF-7 cells (Figure 3C). Finally, blockade of IFN $\alpha$ signaling also reduced ERE (estrogen response element) activity in AI-resistant MCF-7:5C cells, as demonstrated by the luciferase assay shown in Figure 3D. Confirmation of the inhibitors effect on STAT1 and STAT2 at the mRNA level in all cell lines is shown in Figure S1A along with two downstream targets, IFITM1 and IRF9. The same experiments were performed in T47D cells and show little impact on ER $\alpha$ signaling (Figure S1B-D). 


\subsection{STAT1 and STAT2 Expression Affect ER $\alpha$ and ER-Regulated Gene Expression in AI-Resistant} Breast Cancer Cells

Since the JAK/STAT inhibitor Rux dramatically reduced ER $\alpha$ expression in AI-resistant MCF-7:5C cells, we next determined whether inhibition of STAT1 and STAT2 directly impacts ER $\alpha$ expression and function in these cells. We utilized siRNAs to target STAT1 and STAT2 expression in MCF-7:5C and MCF-7 cells. Inhibition of STAT1 and STAT2 reduced total ER $\alpha$ and p-ER $\alpha$ levels in MCF-7:5C cells but not MCF-7 cells (Figure 4A). Notably, loss of STAT1 significantly reduced ERE activity in MCF-7:5C cells (Figure 4B) while loss of STAT1 and STAT2 dramatically reduced the expression of ER-regulated genes in MCF-7:5C cells (Figure 4C, right panel) with no effect in parental MCF-7 cells (Figure 4C, left panel). Confirmation of STAT1 and STAT2 knockdown is shown in Figure 4D along with two downstream targets IFITM1 and IRF9. Similar experiments were performed in T47D cells and although ER $\alpha$ protein level was reduced, ERE luciferase activity and ER-regulated genes were not impacted (Figure S2).

A
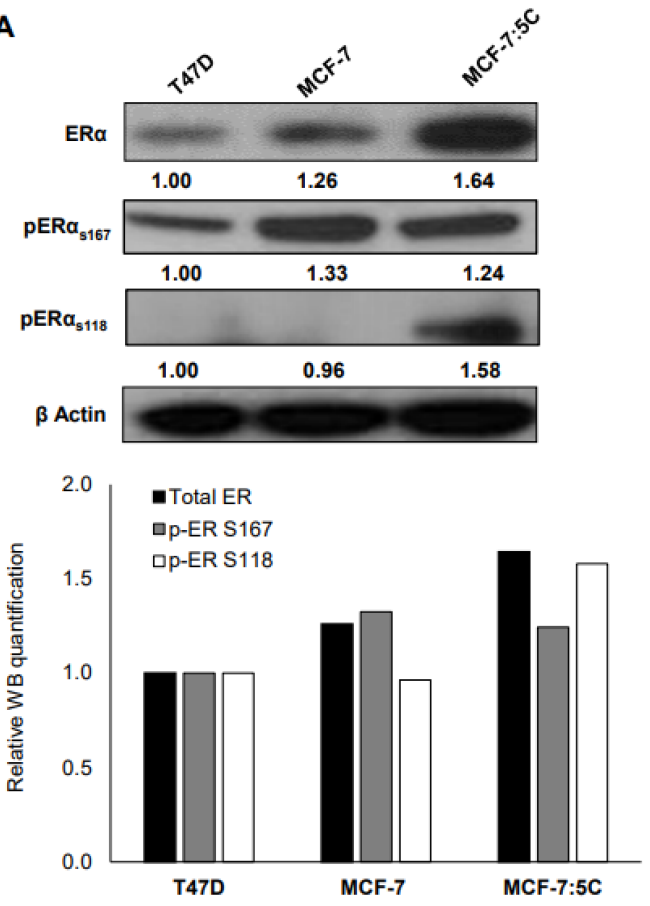

C

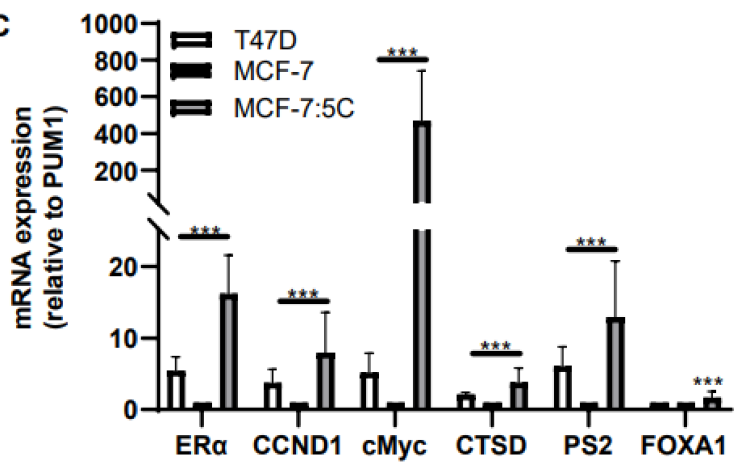

B
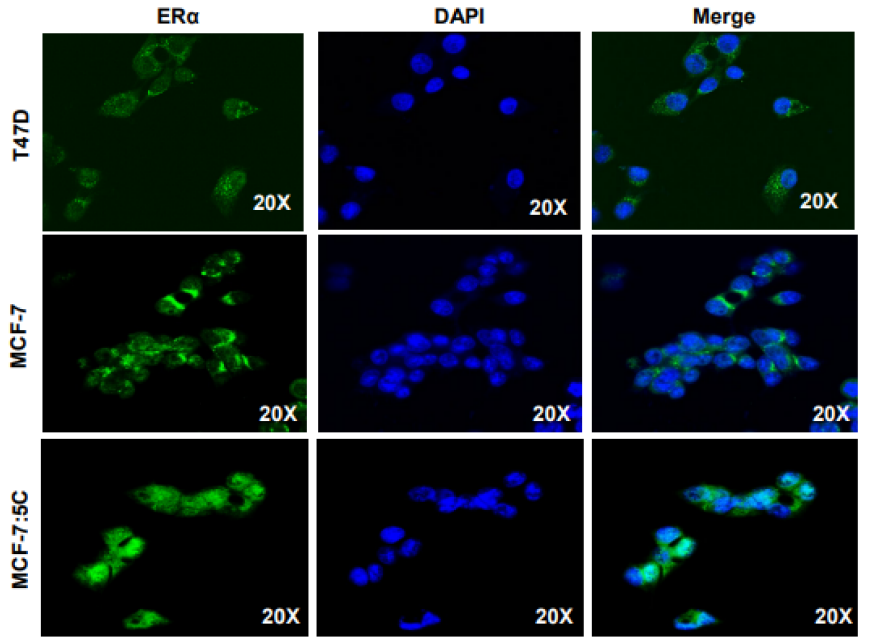

D

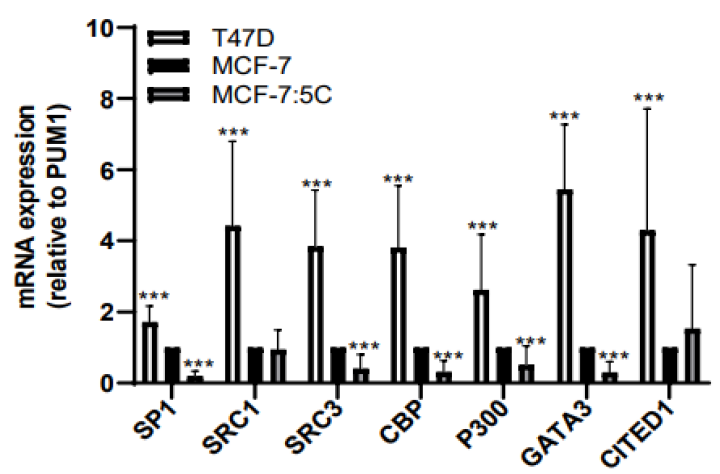

Figure 1. ER $\alpha$ and ER-regulated genes are overexpressed in aromatase inhibitor-resistant breast cancer cells. Cell lysates were subjected to (A) Western blot for ER $\alpha, \mathrm{p}-\mathrm{ER} \alpha \mathrm{S} 167$, and $\mathrm{p}-\mathrm{ER} \alpha \mathrm{S} 118$ protein expression. Image J software was used to quantify levels of each protein relative to T47D. Quantification is shown below blot. (B) Immunofluorescent imaging. (C) RT-PCR for ER $\alpha$, and the ER-regulated genes, CCND1, C-Myc, CTSD, pS2 and FOXA1 mRNA. (D) Transcript levels of ER $\alpha$ coactivators of ER $\alpha$, SP1, SRC1, SRC3, CBP, P300, GATA3 and CITED1, were determined by RT-PCR. Data represent three independent experiments run in triplicate. ${ }^{* * *} p<0.001$. 
A
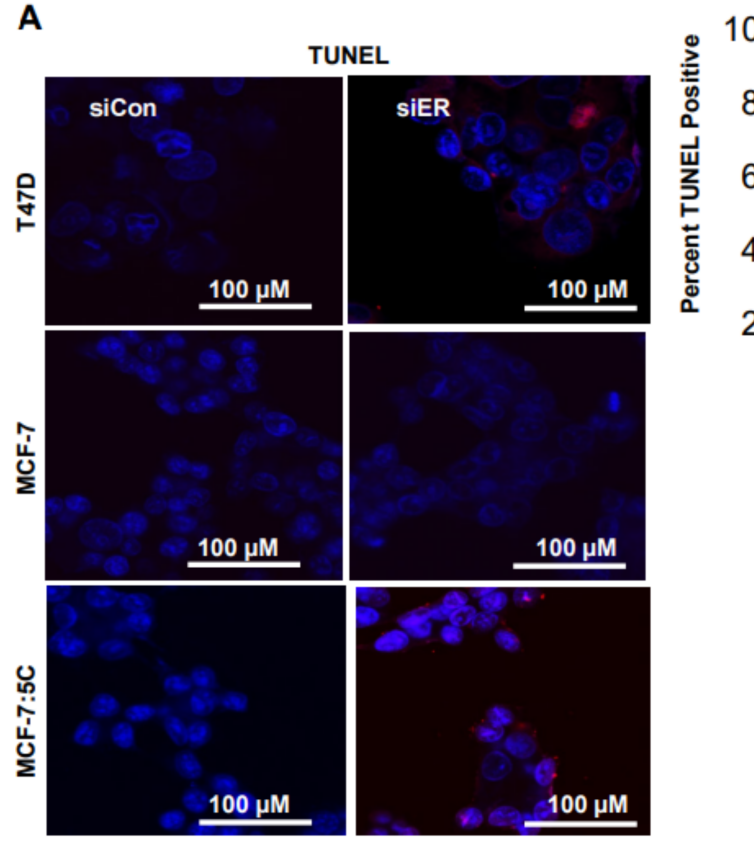

D



B



C
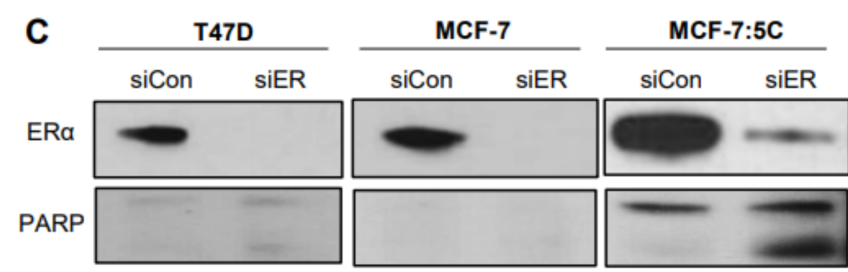

$\beta$ Actin
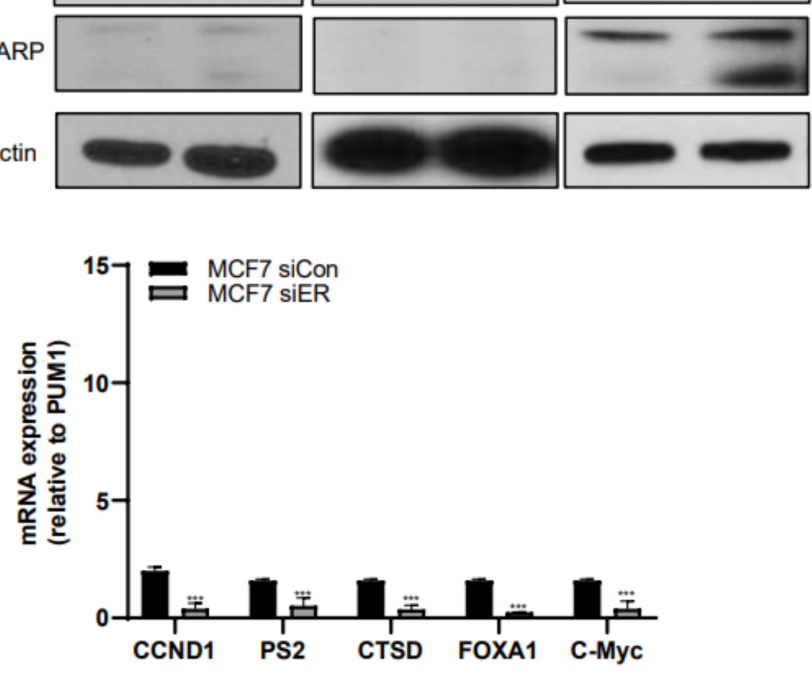

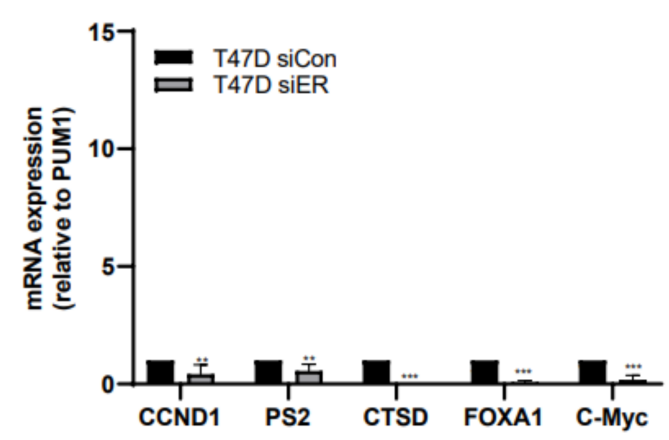

Figure 2. Loss of ER $\alpha$ expression induces apoptosis most prominently in aromatase inhibitor-resistant breast cancer cells. T47D, MCF-7, and MCF-7:5C cells were transiently transfected with siCon or siER and (A) measured for apoptosis by TUNEL staining, which was quantified with Image J Software (right panel); (B) assessed for cell proliferation c using Trypan blue exclusion $72 \mathrm{~h}$ after transfection; (C) immunoblotted for ER $\alpha$ and PARP expression; (D) analyzed by RT-PCR for mRNA expression of ER-regulated genes (CCND1, pS2, CTSD, FOXA1 and C-myc). Data represent three independent experiments run in triplicate. ${ }^{* *} p<0.05$ and ${ }^{* *} p<0.01$. 
A

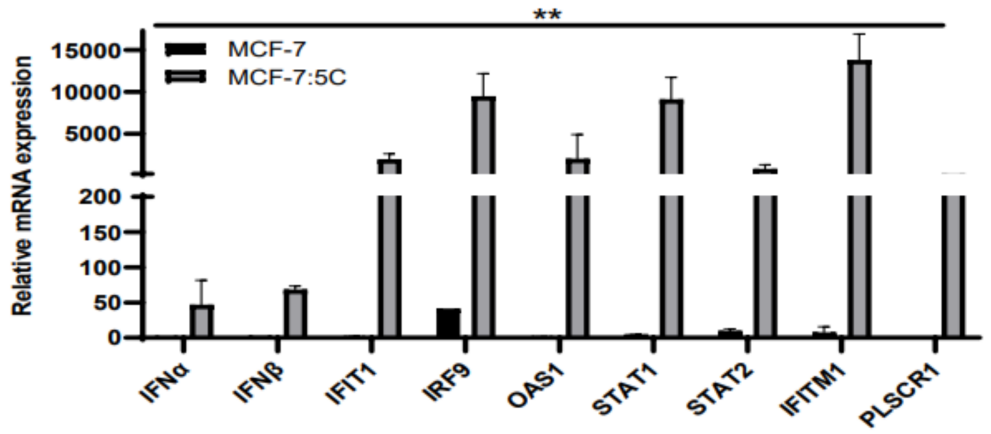

B

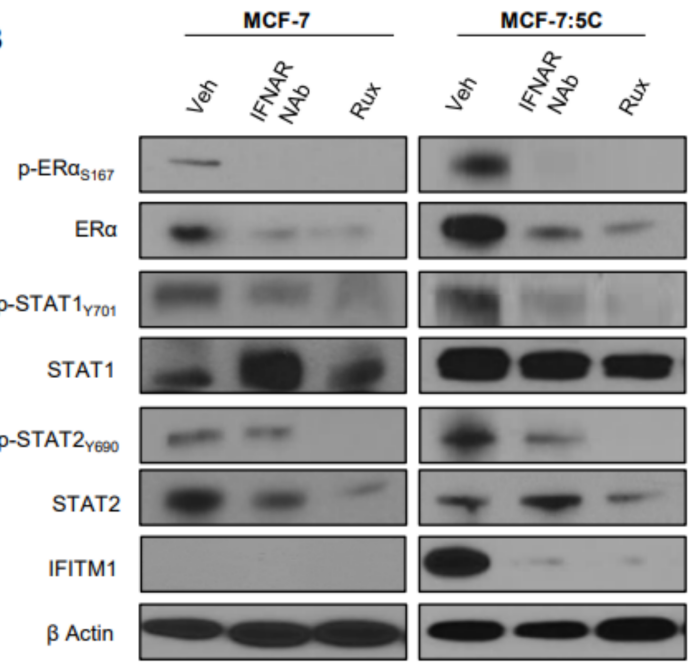

D

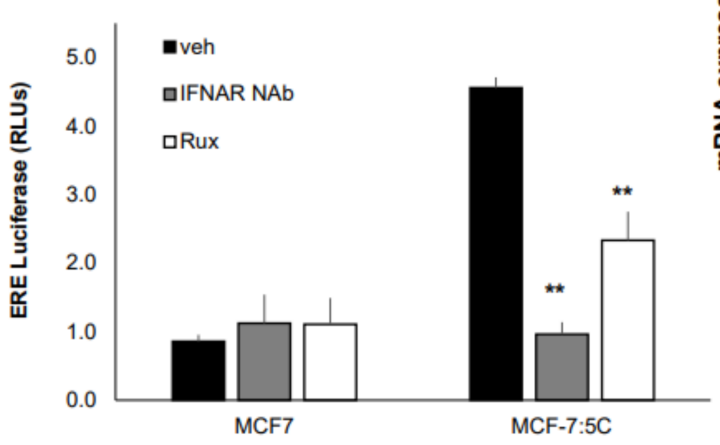

c

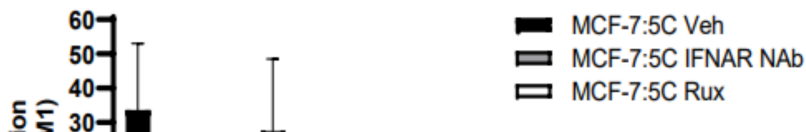

口 MCF-7:5C IFNAR NAb

MCF-7:5C Rux
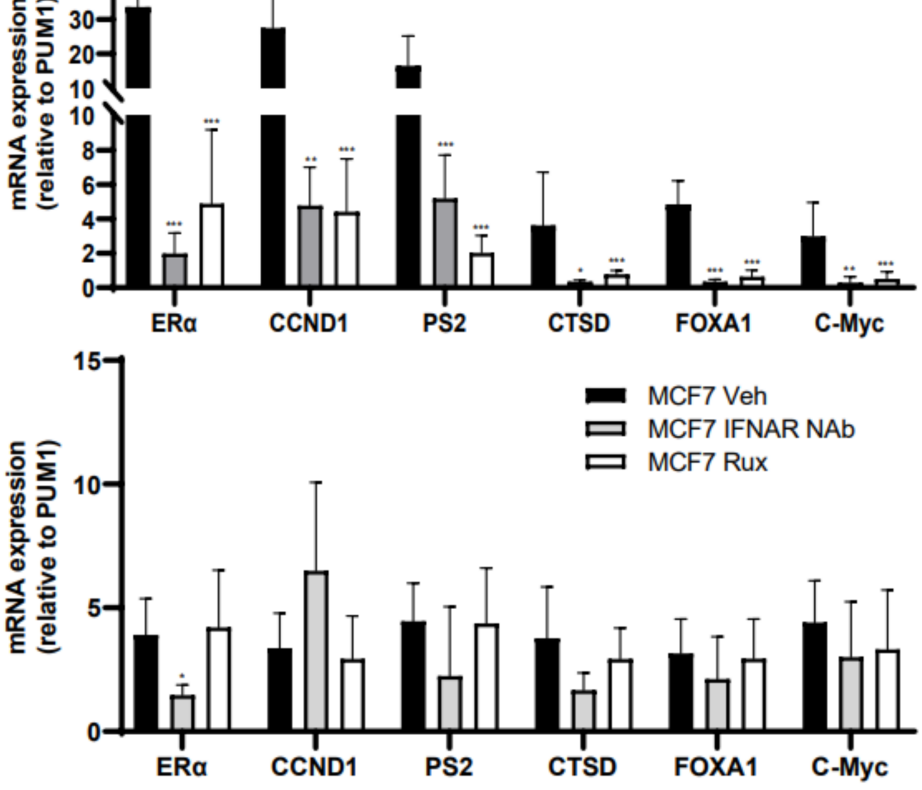

Figure 3. Enhanced IFN $\alpha$ signaling affects $\mathrm{ER} \alpha$ and ER-regulated gene expression in AI-resistant breast cancer cells. (A) MCF-7 and MCF-7:5C cells were analyzed by RT-PCR for interferon-stimulated gene (ISG) expression. (B,C) MCF-7 and MCF-7:5C cells were treated for $48 \mathrm{~h}$ with IFNAR NAb or Rux (as indicated) and immunoblotted for the indicated proteins or analyzed by RT-PCR. (D) MCF-7 and MCF-7:5C cells were transfected with the ERE luciferase construct and then treated with IFNAR NAb or Rux. Luciferase activity was then read. ${ }^{*} p<0.1,{ }^{* *} p<0.05$ and ${ }^{* *} p<0.01$.

\subsection{STAT1 Interacts with ERa through In Silico and In Vitro Analysis in AI-Resistant Breast Cancer Cells}

Our data validated that STAT1 can alter ER $\alpha$ levels, thus we sought to determine whether these proteins physically interact through in silico analysis using the GRAMM-X Protein-protein Docking Web Server v.1.2.0. We found a potential binding site between STAT1 and ER $\alpha$ (Figure 5A). The STAT1 amino acids (denoted in pink) D292, S307, S315, and T489 interact with L544, G339, P337, L416, N413, and M437 of ER $\alpha$ (denoted in green), respectively. Binding occurs within 2.2 to 3.5 angstroms, indicating strong bonds and a relatively stable complex between the STAT1 DNA binding domain and ER $\alpha$ AF2 domain. This suggests that STAT1 may be interacting with ER $\alpha$ in lieu of ligand to cause its activation. In vitro, we validated the interaction between STAT1 and ER $\alpha$ through two 
methods. First, we performed immunoprecipitation of ER $\alpha$ and used Western blotting to detect protein interactions. Only STAT1, not STAT2 or IRF9, interact with ER $\alpha$ in the MCF7:5C cells (Figure 5B). Finally, we utilized proximity ligation assay for STAT1 and ER $\alpha$ and saw predicted interactions solely in the AI-resistant MCF-7:5C cells (Figure 5C). Overall, this finding indicates a novel interaction between STAT1 and ER $\alpha$ in the AI-resistant MCF-7:5C cell line.
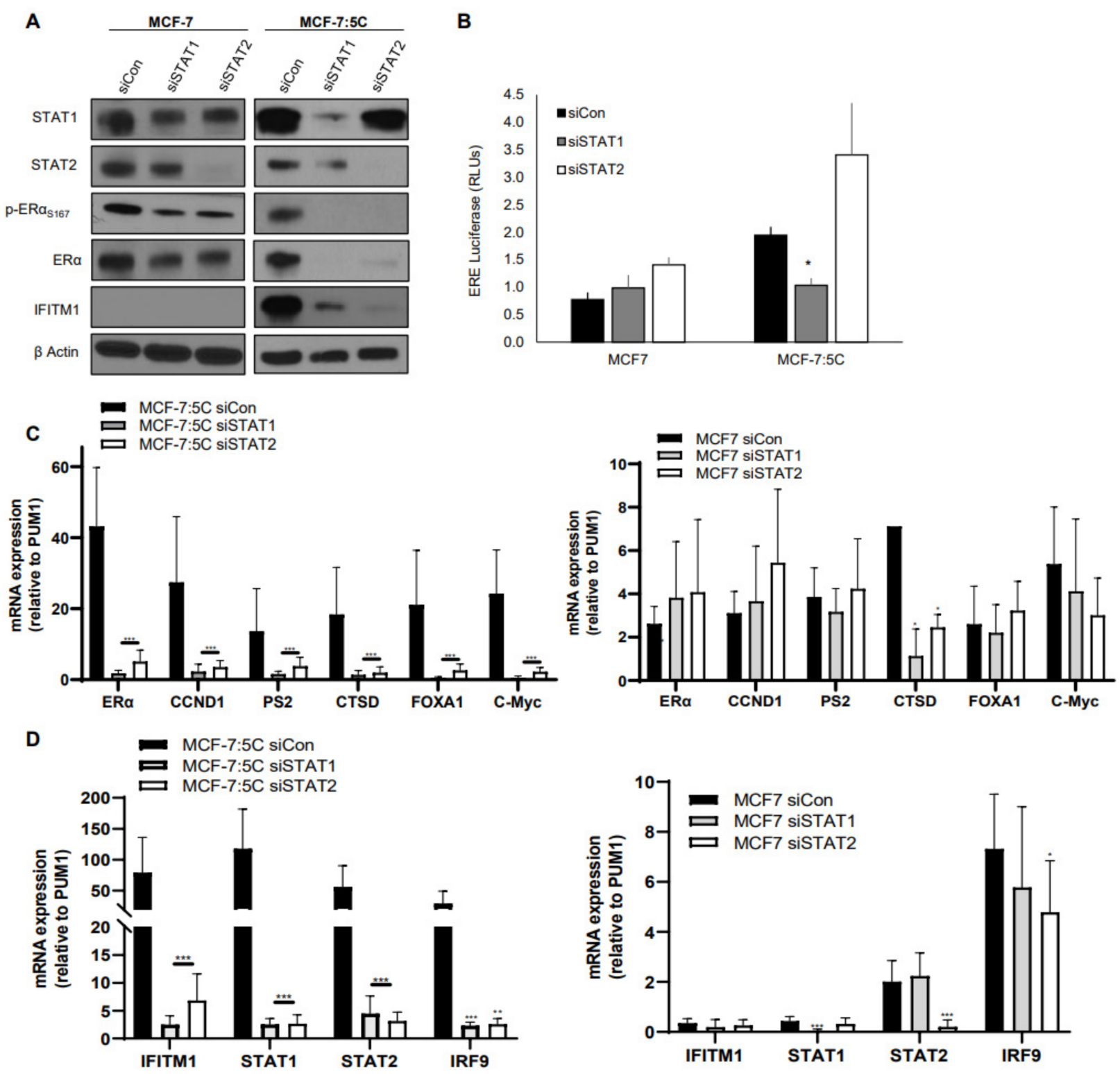

Figure 4. STAT1 and STAT2 expression affect ER $\alpha$ and ER-regulated gene expression in AI-resistant breast cancer cells. (A) MCF-7 and MCF-7:5C cells were transiently transfected for $48 \mathrm{~h}$ with siRNA against STAT1 or STAT2 and immunoblotted for the proteins indicated. (B) MCF-7 and MCF-7:5C cells were transiently transfected for the ERE reporter construct and siRNA against STAT1 or STAT2 for $48 \mathrm{~h}$. Luciferase activity was then read. (C,D) MCF-7 and MCF-7:5C cells were transfected with siCon, siSTAT1, or siSTAT2 (as indicated) and analyzed by RT-PCR. ${ }^{*} p<0.05,{ }^{* *} p<0.01$ and ${ }^{* * *} p<0.001$.

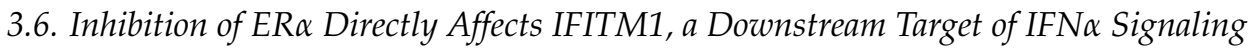

We previously reported that interferon-induced transmembrane protein 1 (IFITM1) is a key regulator of growth and survival in AI-resistant MCF-7:5C cells [11] and its expression correlates with ER $\alpha$ expression. In this experiment, we utilized siRNA knockdown to examine the effect of ER $\alpha$ loss on IFITM1 expression. We found that inhibiting ER $\alpha$ 
markedly reduced IFITM1 expression at the protein (Figure 6A) and the mRNA level (Figure 6B) and it decreased IFITM1 reporter activity and interferon-stimulated response element (ISRE) luciferase activity in MCF-7:5C cells but not MCF-7 or T47D cells (Figure 6C and Figure S3A-C). Notably, loss of ER $\alpha$ also significantly reduced p-STAT1 but not pSTAT2 levels in MCF-7:5C cells, thus confirming an important role for ER $\alpha$ /STAT1 crosstalk in regulating IFITM1.

A

A Surface model



B

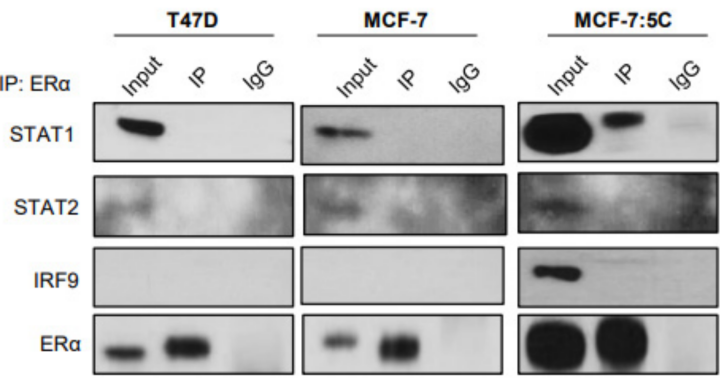

C
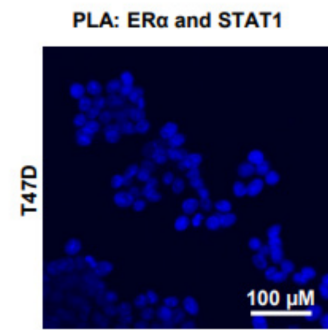

Interacting amino acids Pink: STAT1, Green: ERa
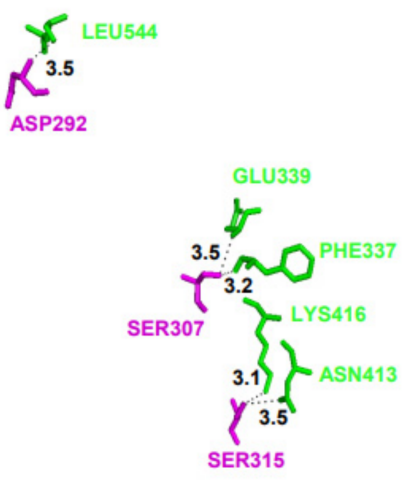

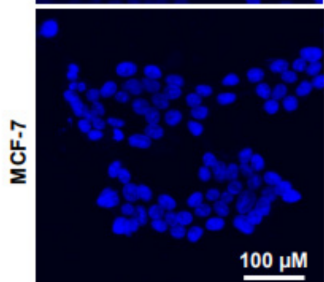

MET 437
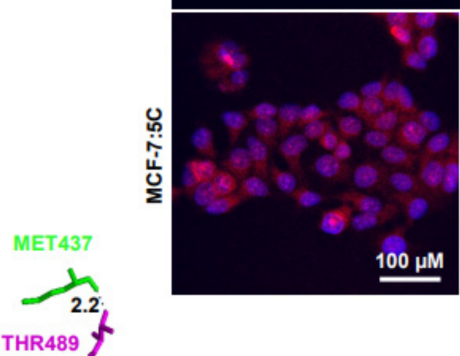

Figure 5. STAT1 interacts with ER $\alpha$ through in silico and in vitro analysis in AI-resistant breast cancer cells. (A) X-ray crystal structures of STAT1 and ER $\alpha$ were downloaded from PDB and prepared for docking by removing ligands, water molecules and extra chain of amino acids. Chain A was selected for both proteins. The proteins were further prepared using MGL tools. The final prepared protein structures were uploaded to the GRAMM-X protein docking server for checking interactions. The final output file was analyzed using PYMOL program. (B) T47D, MCF-7, and MCF-7:5C cells were immunoprecipitated with anti-ER $\alpha$ or rabbit IgG and immunoblotted for STAT1, STAT2, IRF9 and ER $\alpha$. (C) All cell lines were grown on coverslips and processed with the Duolink ${ }^{\circledR}$ PLA Fluorescence with ER $\alpha$ and STAT1 antibodies.

\subsection{ER $\alpha$ and STAT1 Regulate IFITM1 through Binding to ERE and ISRE Elements in the Promoter}

To investigate whether ERa and STAT1 directly bind to the IFITM1 promoter, we first determined whether there were any ERE binding sites in the IFITM1 promoter. Utilizing the UCSC Genome Browser, we searched previously uploaded chromatin immunoprecipitation data from Tamoxifen-resistant cells for ERE-like sequences. We found multiple ERE-like sequences (AGGTCACCCTGACCT) within the IFITM1 promoter at $30 \mathrm{kB}$ upstream and 
45,85 , and $100 \mathrm{kB}$ downstream of the start site (Figure 7A). Next, we performed chromatin immunoprecipitation in all three of our cell lines with primers selective for each of the EREs and the well-known ISRE in the IFITM1 promoter (Figure 7B and Figure S3D). We found that STAT1 and ER $\alpha$ were recruited to the ERE of IFITM1 in AI-resistant cells and to the ISRE. In MCF-7:5C cells the maximum ER $\alpha$ binding occurred at the $100 \mathrm{kB}$ ERE $(3.0 \times)$ with the lowest binding at $45 \mathrm{kB}$ ERE $(1.9 \times)$ when compared to the IgG. The maximum STAT1 binding was observed at the $100 \mathrm{kB}$ ERE site $(2.7 \times)$ and the lowest binding at the $45 \mathrm{kB}$ ERE $(1.7 \times)$ compared to the IgG. Overall, these data suggest that both STAT1 and $\mathrm{ER} \alpha$ bind to the ERE sites within the IFITM1 promoter as well as the ISRE element. The strongest binding of both proteins occurs at the $100 \mathrm{kB}$ ERE site. The MCF-7 and T47D cells (Figure S3) did not have significant binding of STAT1 or ER $\alpha$ to any of these sites within the IFITM1 promoter.

A

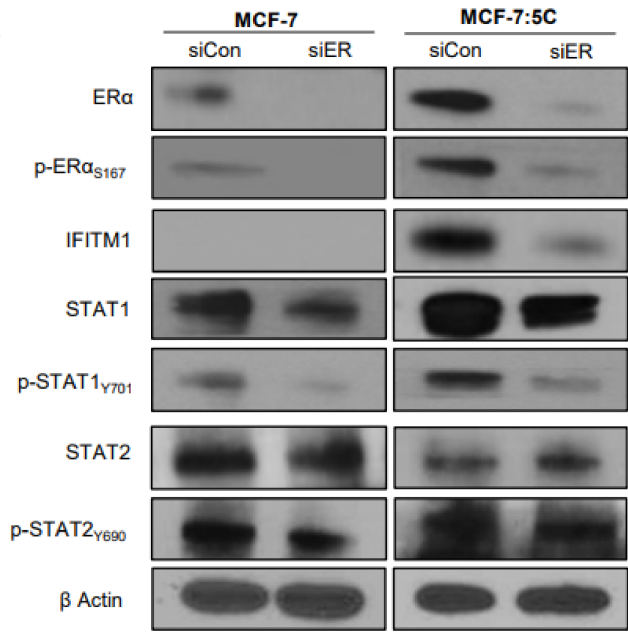

C

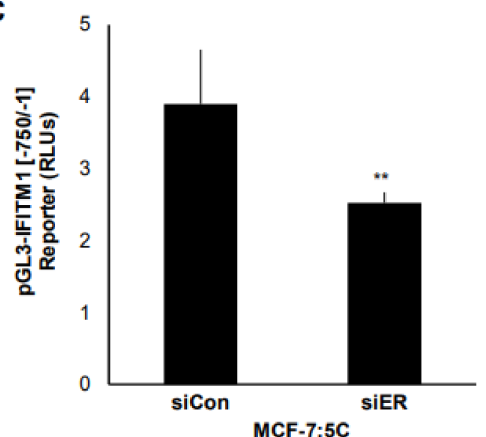

D

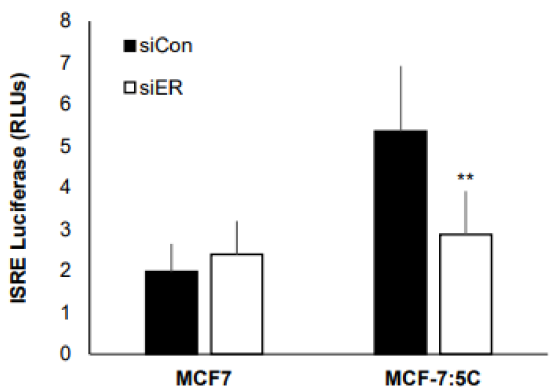

B
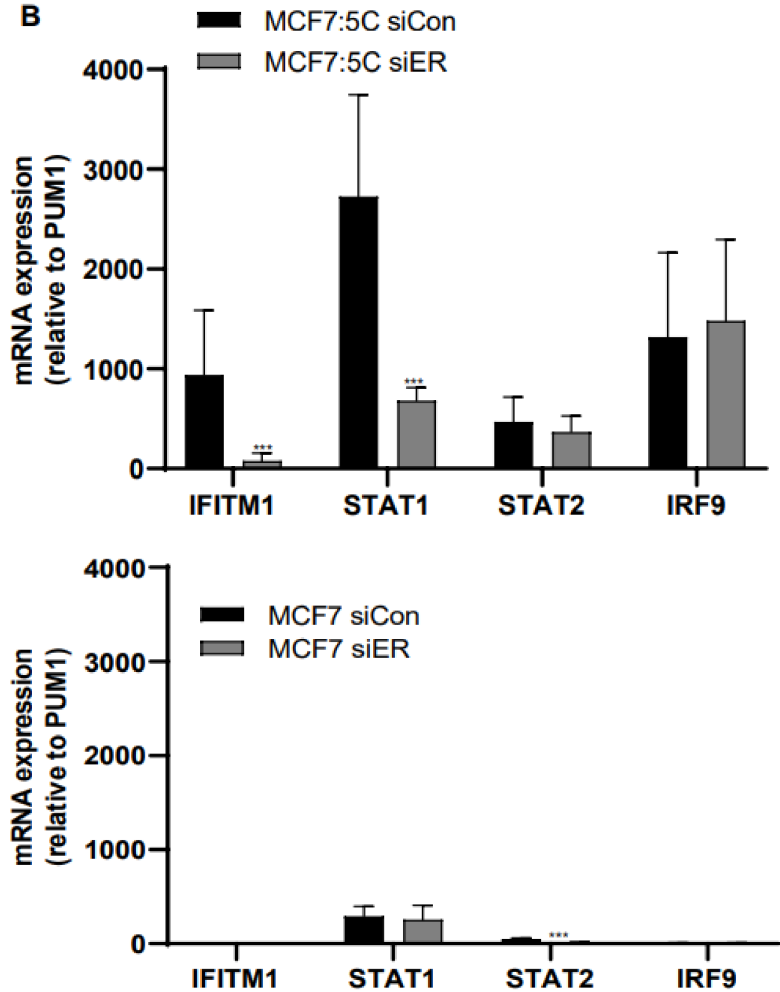

Figure 6. Inhibition of ER $\alpha$ directly affects IFITM1, a downstream target of IFN $\alpha$ signaling. MCF-7 and MCF-7:5C cells were transiently transfected for $48 \mathrm{~h}$ with siRNA against ER $\alpha$ and (A) immunoblotted for the proteins indicated; (B) analyzed by RT-PCR. (C) MCF-7:5C cells were transiently transfected for the IFITM1 promoter construct and siRNA against ER $\alpha$ for $48 \mathrm{~h}$. (D) MCF-7 and MCF-7:5C cells were transfected with the ISRE reporter construct and siRNA against ER $\alpha$ for $48 \mathrm{~h}$. Luciferase activity was read. ${ }^{* *} p<0.05^{* * *} p<0.001$. 
A

ER binding site in IFITM1 promoter

IFITM1
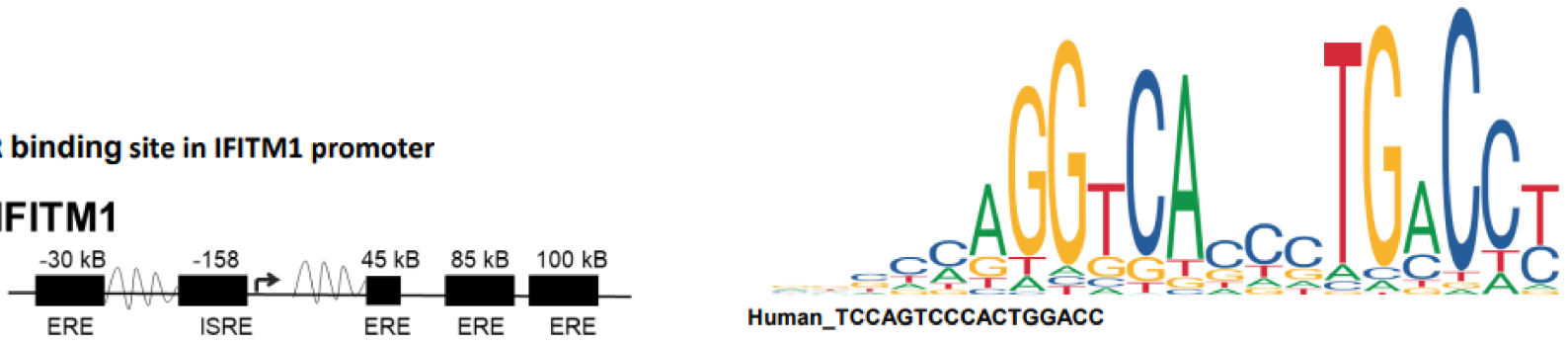

B
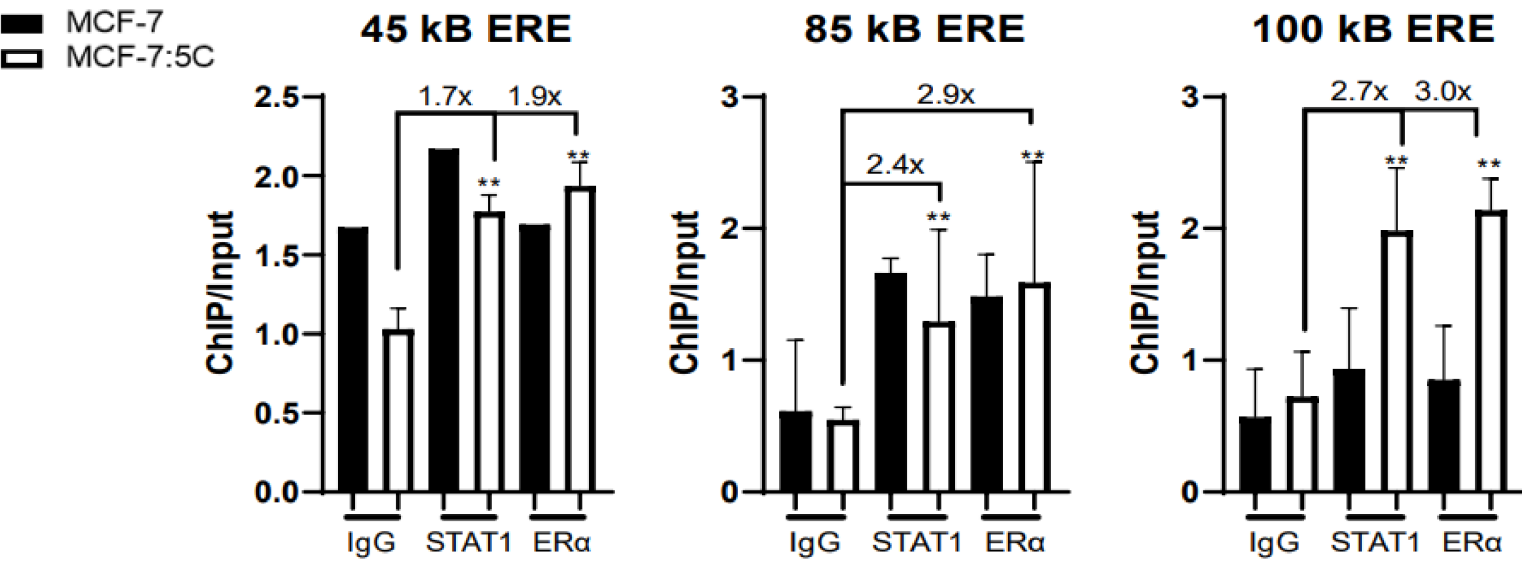

$-30 \mathrm{kB}$ ERE

-158 ISRE
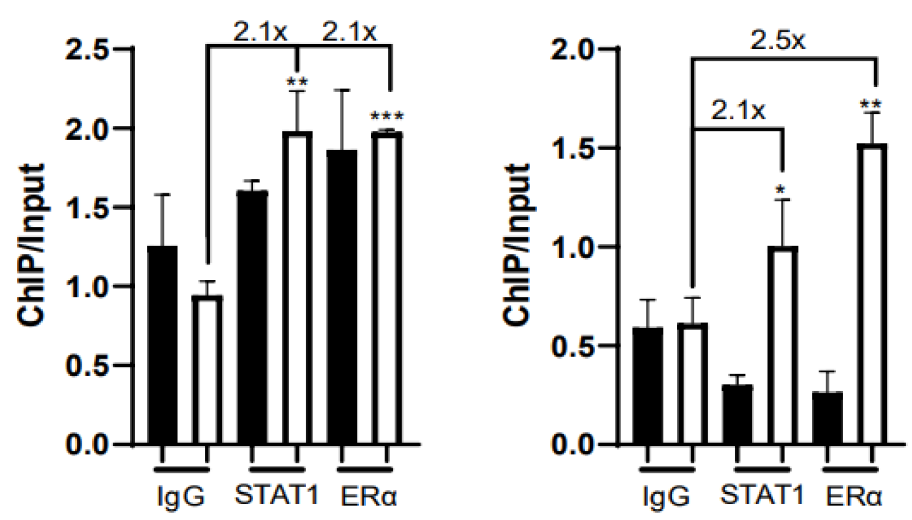

Figure 7. ER $\alpha$ and STAT1 regulate IFITM1 through binding to ERE and ISRE elements in the promoter. (A) ChIP data from Tam-resistant breast cancer cells from the UCSC Genome Browser were analyzed for potential ER $\alpha$ binding sites. (B) Chromatin immunoprecipitation (ChIP) with antibodies against ER $\alpha$, STAT1 or species-specific IgG control was performed and analyzed by qPCR and DNA gels on the isolated DNA using primers designed to amplify the ERE and ISRE regulatory regions. Recruitment of the indicated proteins to the ERE and ISRE site was compared to input DNA and displayed as mean $\pm \mathrm{SD}$ of technical triplicates in two independent experiments. ${ }^{*} p<0.5,{ }^{* *} p<0.05$ and ${ }^{* * *} p<0.001$.

\subsection{E $E_{2}$ Treatment Inhibits IFITM1 Expression and Blocks ER $\alpha$ and STAT1 Recruitment to the} IFITM1 Promoter

Based on the observation that $\mathrm{ER} \alpha$ was transcriptionally active in our AI-resistant MCF-7:5C cells and that ER $\alpha / S T A T 1$ interaction regulates IFITM1 expression in these cells, we assessed the impact of $\mathrm{E}_{2}$ on ER $\alpha$ function and ER-mediated regulation of IFITM1 expression. Western blot and RT-PCR analyses revealed that $\mathrm{E}_{2}$ treatment completely reduced IFITM1 protein (Figure 8A) and IFITM1 mRNA (Figure 8B) expression in AI-resistant MCF7:5C cells. Additionally, ChIP assays revealed that there was significant ligand-independent recruitment of ER $\alpha$ and STAT1 to the IFITM1 promoter at the location of the ERE sites in MCF-7:5C cells; however, in the presence of $E_{2}$, the binding of both STAT1 and ER $\alpha$ 
to the IFITM1 promoter was markedly reduced (Figure 8C). Taken together, these data indicate that in AI-resistant MCF-7:5C cells, $\mathrm{E}_{2}$ acts in a paradoxical manner to suppress $\mathrm{ER} \alpha$ function and thus block its potential crosstalk with the IFN $\alpha$ signaling pathway.

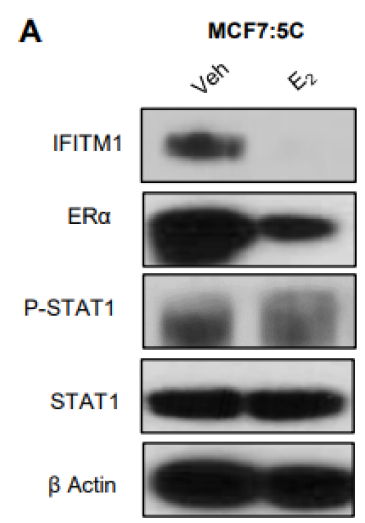

B

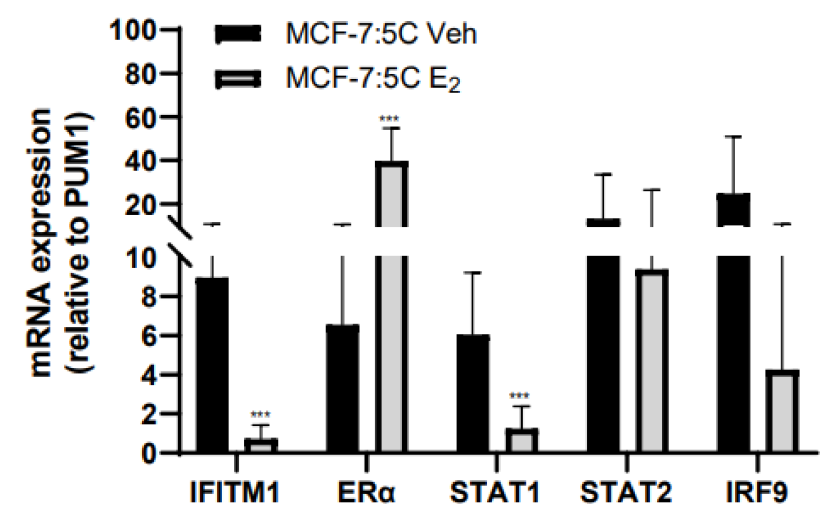

C

45 kB ERE

85 kB ERE

100 kB ERE


-30 kB ERE

-158 ISRE


Figure 8. $\mathrm{E}_{2}$ treatment inhibits IFITM1 expression and blocks ER $\alpha$ and STAT1 recruitment to the IFITM1 promoter. MCF-7:5C cells were treated for $48 \mathrm{~h}$ with $\mathrm{E}_{2}$ and (A) immunoblotted for ER $\alpha, \mathrm{p}$-STAT1, STAT1, and IFITM1 expression; (B) analyzed by RT-PCR. (C) Chromatin immunoprecipitation (ChIP) with antibodies against ER $\alpha$, STAT1 or species-specific IgG control was performed and analyzed by qPCR and DNA gels on the isolated DNA using primers designed to amplify the ERE and ISRE regulatory regions. Recruitment of the indicated proteins to the ERE and ISRE site was compared to input DNA and displayed as mean $\pm \mathrm{SD}$ of technical triplicates in two independent experiments. ${ }^{*} p<0.5,{ }^{* *} p<0.05$ and ${ }^{* *} p<0.001$. 


\section{Discussion}

Estrogen deprivation through AIs is the first-line treatment for ER+ breast cancer patients; however, resistance develops in approximately $30 \%$ of patients. Understanding the mechanism by which AI resistance occurs is of great clinical importance. We sought to investigate the mechanisms of AI resistance in our MCF-7:5C cell line. Previous findings from our lab demonstrate enhanced IFN $\alpha$ signaling in AI-resistant cells, which is key in mediating cell survival. In this study, we show for the first time that IFN $\alpha$ signaling is enhanced in AI-resistant MCF-7:5C cells and promotes ligand-independent regulation of ER $\alpha$ primarily through STAT1. This novel interaction may explain why these AIresistant cells retain expression of $\mathrm{ER} \alpha$ and continue to grow in estrogen-free conditions. Pharmacologically targeting the interaction between IFN $\alpha$ signaling and $E R \alpha$ may improve survival outcomes of patients with AI-resistant breast cancer.

The AI-resistant MCF-7:5C cells show enhanced expression of ER $\alpha$ compared to the MCF-7 and T47D AI-sensitive cells (Figure 1A). In addition, they have elevated levels of p-ER $\alpha$ at both the S167 and S118 residues and primarily nuclear localization of ER $\alpha$, indicating that $\mathrm{ER} \alpha$ is in an activated state (Figure 1A,B). Enhanced phosphorylation of $\mathrm{ER} \alpha$ through coactivators can drive AI-resistant survival of breast cancer cells [52]. When $\mathrm{ER} \alpha$ is activated (via ligand binding or phosphorylation), it begins transcription of its target genes. We saw enhanced expression of multiple ER-regulated genes (CCND1, pS2, CTSD, FOXA1, and c-Myc) in the AI-resistant cells (Figure 1C). Surprisingly, in the AI-resistant MCF-7:5C cells, the ER $\alpha$ coactivators (SP1, SRC1, SRC3, CBP, P300, GATA3, and CITED1) had much lower basal activation (Figure 1). This could indicate that in AI-resistant cells, JAK/STAT signaling is acting as a coactivator in lieu of these other proteins. It is paramount to reiterate that the expression and localization of ER $\alpha$ occurs in the absence of estrogen in the AI-resistant MCF-7:5C cells. In comparison, the levels of ER $\alpha$ in MCF-7 and T47D cells are shown under estrogen containing conditions (Figure 1). This suggests that the AI-resistant MCF-7:5C cells have a ligand-independent mechanism of activating ER $\alpha$ via phosphorylation that turns on ER-regulated genes. We hypothesize that this is through the enhanced IFN $\alpha$ signaling previously demonstrated in this cell line and that IFN $\alpha$ signaling is compensating for the loss of estrogen and continuing to activate $\mathrm{ER} \alpha$, which promotes AI-resistant cell survival.

Preclinical and clinical studies suggest an interaction between the IFNs and estrogen signaling pathways that leads to progression of breast cancer [53-56]. These studies highlight IRF-1, a target gene of JAK-STAT signaling, in acquired anti-estrogen and tamoxifen resistance [57-60]. This would offer a possible explanation as to why many breast tumors retain $E R \alpha$ expression but become resistant to treatment targeting $E R \alpha$ signaling. $E R \alpha$ is known to induce transcription of Jak2 in MCF-7 cells and the STAT proteins in endothelial cells and to promote IRF7-dependent expression of IFN $\alpha$ in plasmacytoid dendritic cells $[35,61,62]$. In addition, STAT1/3/5 has been shown to influence ER $\alpha$ in cancer and other diseases and the ISG, IFI27, can directly downregulate ER $\alpha$ expression [63-65]. A recent study from Hou et al. identified the involvement of STAT1 in facilitating ER $\alpha$ transcription in the Tamoxifen-resistant MCF-7: LCC2 cell line and this cell line showed overexpression of multiple ISGs, including IFITM1 [66]. This supports our hypothesis that IFN $\alpha$ can promote breast cancer progression through enhanced ER $\alpha$ signaling. Notably, our PLA and co-immunoprecipitation experiments indicate a direct interaction between $\mathrm{ER} \alpha$ and STAT1 in AI-resistant MCF-7:5C cells, which was not observed in AI-sensitive MCF-7 and T47D cells (Figure 5). We have previously investigated the interaction between MUC1 and STAT1 in AI-resistant cells [42]. MUC1 is a well-known regulator of ER $\alpha$ and may facilitate the binding of STAT1 in activating ligand-independent signaling of ER $\alpha$; however, this requires further investigation.

We found that blocking IFN $\alpha$ and JAK/STAT signaling through genetic and pharmacological mechanisms inhibits ER $\alpha$ expression (both total and S167 levels) and ER-regulated genes in the MCF-7:5C cells (Figures 3 and 4). This indicates that JAK/STAT activation contributes to ER $\alpha$ phosphorylation. S118 and S167 reside in the AF-1 domain of ER $\alpha$ 
and upon phosphorylation contribute to ligand-independent activation and transcription of ER-regulated genes, including recruitment of co-activators [67]. Crosstalk with other signaling pathways $[52,68,69]$ and mutations within the ligand binding domain of ER $\alpha$ can also cause ligand-independent activation and lead to therapy resistance [70-72]. We should note, however, that AI-resistant MCF-7:5C cells express only the wild-type ER $\alpha$ and not any of the previously published mutant $\mathrm{ER} \alpha$ variants. There is also evidence that progesterone receptor $(\mathrm{PR})$, another steroid receptor, suppresses expression of ISGs [73,74]. However, with long-term estrogen deprivation, MCF-7:5C cells lose PR expression. We hypothesize that without PR, this suppression is blocked, enhancing IFN $\alpha$ signaling and ISG expression possibly contributing to ligand-independent activation of ER $\alpha$.

$E R \alpha$ plays a key role in modulating many signaling pathways. Here, we show that ER $\alpha$ directly regulates the IFN $\alpha$ signaling pathway and its downstream target IFITM1. IFITM1 has proven key in our AI-resistant cells in promoting their growth and survival [11,26]. In this study, downregulation of ER $\alpha$ caused a reduction in IFITM1 mRNA and protein expression and promoter activity. We went on to probe previous chromatin immunoprecipitation data using the UCSC Genome Browser, for potential ER $\alpha$ binding sites near the IFITM1 promoter. In canonical signaling, ER $\alpha$ binds to estrogen response elements (EREs) or ERE half-sites of promoters of estrogen-responsive genes promoting cell cycle progression and growth [34,75]. However, one-third of genes regulated by ER $\alpha$ lack ERE sequences and $\mathrm{ER} \alpha$ non-canonically regulates signaling by binding to GC-rich promoter sequences and through tethered protein-protein interactions [34-37]. Our ChIP data confirmed that $\mathrm{ER} \alpha$ directly binds to multiple ERE sites within the IFITM1 promoter and can bind in conjunction with STAT1 at these sites and the ISRE element in the AI-resistant MCF-7:5C cells (Figure 7). Hence, this finding suggests that ER $\alpha$ may regulate ISGs to promote cell survival and it indicates a potential crosstalk between ER $\alpha$ and the JAK/STAT signaling pathway in driving this process.

AI-resistant MCF-7:5C cells grow robustly in the absence of estradiol $\left(\mathrm{E}_{2}\right)$; however, in the presence of $E_{2}$, these cells undergo in vitro and in vivo cell death [40-42,51,76,77]. The cytotoxic effect of estrogen on AI-resistant cells have been verified through multiple pre-clinical studies $[11,76]$ and low-dose estrogen is being clinically investigated in patients with resistant breast cancer [78-81]. Consistent with this paradoxical action of estrogen, we found that $\mathrm{E}_{2}$ treatment suppresses IFN $\alpha$ signaling and IFITM1 expression and it diminishes some ER $\alpha$-mediated actions in AI-resistant MCF-7:5C cells. Notably, estrogen treatment also reduces activation of ER $\alpha$ and blocks ER $\alpha$ and STAT1 binding to the IFITM1 promoter at both the ISRE and the ERE sites (Figure 8). The ability of $\mathrm{E}_{2}$ to suppress IFN $\alpha / J A K-S T A T$ signaling in AI-resistant MCF-7:5C cells highlights the importance of this pathway in promoting survival in these cells and it supports previous data demonstrating the paradoxical action of $\mathrm{E}_{2}$ in these cells.

The current study suggests that identifying tumors with high expression of IFN $\alpha$ signaling, through a panel of ISGs, before second-line therapy could further improve treatment outcomes for AI-resistant breast cancer patients. These AI-resistant tumors could then be treated with inhibitors of the IFN $\alpha$ signaling pathway (via an IFNAR NAb or JAK/STAT inhibitor), thus blocking the IFN $\alpha$ signaling pathway. In addition, combination therapy using exogeneous estrogen would further suppress the IFN $\alpha$ signaling pathway and promote estrogen-induced apoptosis. Individually, these treatments have been studied clinically $[43,78,82]$; however, the combination of low-dose estrogen and Ruxolitinib (Jakafi ${ }^{\mathrm{TM}}$ ) has yet to be investigated in AI-resistant breast cancer. Based on our data, we hypothesize that combination treatment may be most effective to maintain tumor regression in a subset of AI-resistant patients. One limitation of these studies is that the mechanisms of resistance we investigated are restricted to MCF-7-derived cells. Other models of AI resistance (such as T47D cells) lose expression of ER $\alpha$. To study the effects of IFN $\alpha$ signaling on ligand-independent activation of ER $\alpha$, additional ER+ AI-resistant models need to be developed and investigated. Our studies are also limited as they were conducted in breast cancer cells free from the effects of the tumor microenvironment, which 
has significant effects on tumor progression and therapy resistance $[52,69,83]$. This limits the ability to translate these findings into the clinical setting. However, our previous research has demonstrated that estrogen and Rux treatment in vivo effectively reduces tumor progression [42]. It is critical for future studies to understand how crosstalk between $\mathrm{E}_{2}, \mathrm{ER} \alpha$, and IFN $\alpha$ signaling are mediated by the cells within the tumor microenvironment.

\section{Conclusions}

Overall, our data show that a unique phenotype exists in our AI-resistant MCF7:5C cells. Upon long-term estrogen deprivation, hyperactivation of the IFN $\alpha$ signaling pathway leads to not only activated JAK/STAT signaling and overexpression of ISGs, but also ligand-independent activation of ER $\alpha$. This may be through activation of ER $\alpha$ via phosphorylation of S167 and through co-activation of ER $\alpha$ by STAT1. This continues to cause increased proliferation of the AI-resistant cells through enhanced expression of many pro-survival proteins that are regulated by ER $\alpha$ including IFITM1 (Figure 9). This novel interaction shows that AI-resistant cells can be targeted through multiple mechanisms. Estrogen, the JAK/STAT inhibitor, Ruxolitinib, or inhibitors of other ER $\alpha$ and JAK/STAT coactivators could effectively treat AI-resistant patients or IFITM1-expressing breast cancer in combination [42]. Future studies are needed to determine the exact role that IFN $\alpha$ signaling has on ER $\alpha$ signaling in AI-resistant cells and how the tumor microenvironment impacts this crosstalk.

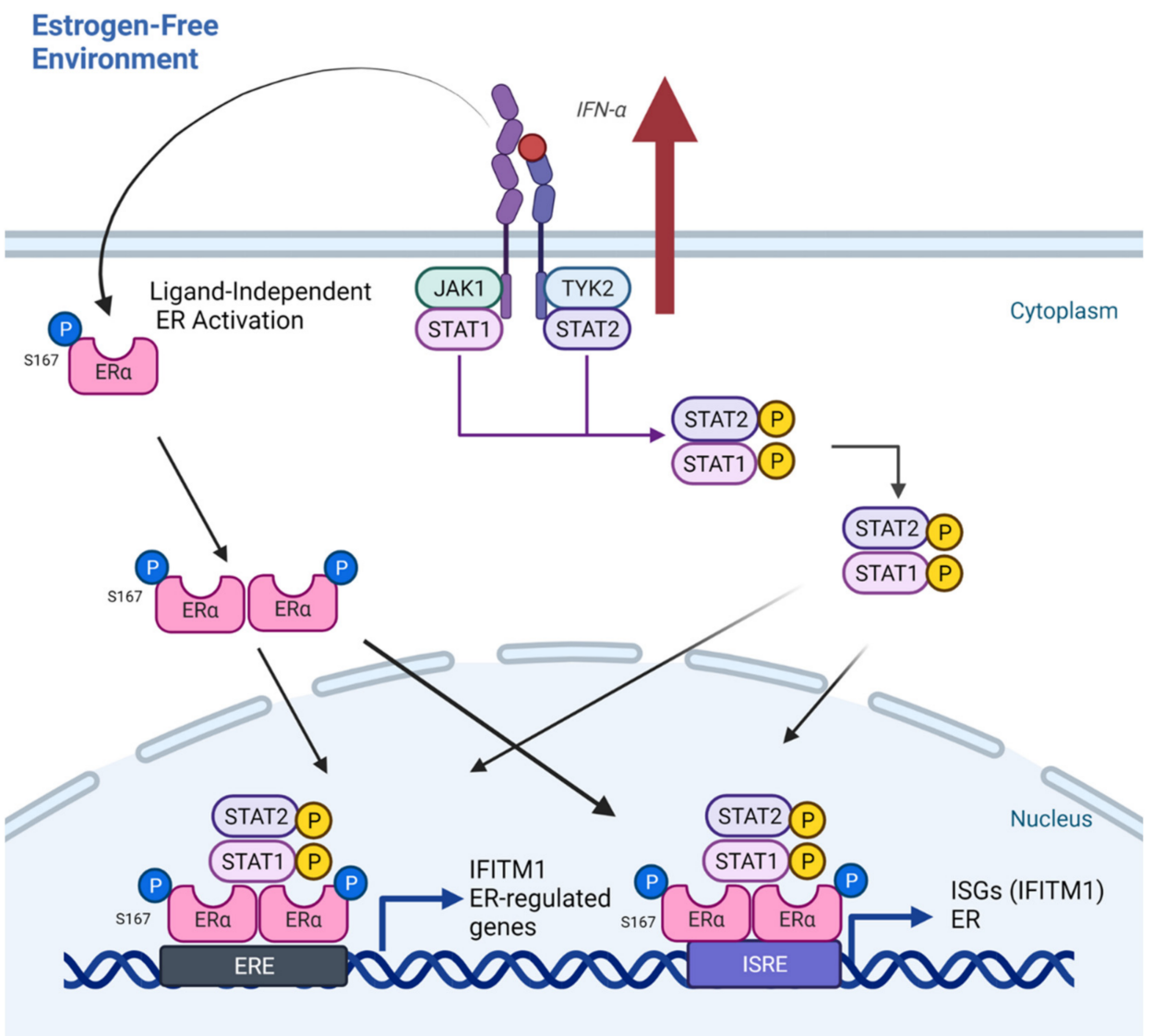

Figure 9. Proposed mechanism of enhanced IFN $\alpha$ signaling on ligand-independent expression of ER $\alpha$ in driving AI resistance and IFITM1 expression. Enhanced IFN $\alpha$ signaling seen in the AI-resistant MCF-7:5C cells upregulates JAK/STAT signaling and expression of not only ISGs but also ER $\alpha$. This enhanced signaling also promotes ligand-independent activation of ER $\alpha$ through phosphorylation of the S167 residue. STAT1 and ER $\alpha$ then function as co-activators of not only ER-regulated genes but also of IFITM1 by binding directly to its promoter which increases survival signaling in AI-resistant cells. (Figure created with Biorender.com.) 
Supplementary Materials: The following are available online at https: / www.mdpi.com/article/ 10.3390 / cancers 13205130 /s1, Figure S1. IFN $\alpha$ signaling inhibition on ER $\alpha$ in T47D cells; Figure S2. STAT1 and STAT2 signaling inhibition on ER $\alpha$ in T47D cells; Figure S3. Loss of ER $\alpha$ affects IFITM1 expression in T47D cells but is not recruited to its promoter; Table S1. ChIP and RT-PCR primers.

Author Contributions: Conceptualization, T.E.E. and J.L.-W.; data curation, T.E.E., A.S., P.D., C.R.H., S.A. and J.L.-W.; formal analysis, T.E.E., A.S., P.D., C.R.H. and J.L.-W.; funding acquisition T.E.E. and J.L.-W.; investigation, T.E.E., A.S., P.D., C.R.H., S.A. and J.L.-W.; methodology, T.E.E., A.S., P.D., C.R.H., S.A. and J.L.-W.; supervision, J.L.-W.; validation T.E.E. and J.L.-W.; visualization, T.E.E., P.D. and J.L.-W.; writing-original draft, T.E.E. and J.L.-W.; writing-review and editing, T.E.E., A.S., P.D., C.R.H. and J.L.-W. All authors have read and agreed to the published version of the manuscript.

Funding: This research was supported, in part, by grants from the National Institutes of HealthNational Cancer Institute (K01CA120051), the Department of Defense (W81XWH-12-1-0139), the American Cancer Society (IRG-09-062-06), the Geographic Management of Cancer Health Disparities Program (GMaP) Region 3, a Supplement of the National Institutes of Health grant P30 CA118100 (Willman, CL), and the University of Kansas School of Medicine Investigator Assistance Award. Pilot funds from the NCI-supported University of Kansas Cancer Center Support Grant (CCSG, P30CA168524-0) and the KUMC Biomedical Research Training Program (BRTP) also supported this work. The content is solely the responsibility of the authors and does not necessarily represent the official views of the National Institutes of Health.

Institutional Review Board Statement: Not applicable.

Informed Consent Statement: Not applicable.

Data Availability Statement: The data presented in this study are available from the corresponding author upon request.

Acknowledgments: We acknowledge the following cores at the University of Kansas Medical Center: the Kansas Intellectual and Developmental Disabilities Research Center (KIDDRC) at the, which is sponsored, in part, by the NIH cooperative agreement grant, U54 HD09216, and the Confocal Imaging Core, which is supported in part, by NIH/NIGMS COBRE grant P30GM122731 (The Leica STED microscope is supported by NIH1S10OD023625). Figure 9 was created with BioRender.com.

Conflicts of Interest: The authors declare no conflict of interest.

\section{References}

1. DeSantis, C.E.; Ma, J.; Goding Sauer, A.; Newman, L.A.; Jemal, A. Breast cancer statistics, 2017, racial disparity in mortality by state. CA A Cancer J. Clin. 2017, 67, 439-448. [CrossRef] [PubMed]

2. Anderson, W.F.; Katki, H.A.; Rosenberg, P.S. Incidence of breast cancer in the United States: Current and future trends. J. Natl. Cancer Inst. 2011, 103, 1397-1402. [CrossRef] [PubMed]

3. Bernstein, L. Epidemiology of endocrine-related risk factors for breast cancer. J. Mammary Gland. Biol. Neoplasia 2002, 7, 3-15. [CrossRef] [PubMed]

4. Seitz, H.K.; Maurer, B. The relationship between alcohol metabolism, estrogen levels, and breast cancer risk. Alcohol Res. Health 2007, 30, 42-43.

5. Cheang, M.C.; Martin, M.; Nielsen, T.O.; Prat, A.; Voduc, D.; Rodriguez-Lescure, A.; Ruiz, A.; Chia, S.; Shepherd, L.; Ruiz-Borrego, M.; et al. Defining breast cancer intrinsic subtypes by quantitative receptor expression. Oncologist 2015, 20, 474-482. [CrossRef]

6. Tobin, N.P.; Foukakis, T.; De Petris, L.; Bergh, J. The importance of molecular markers for diagnosis and selection of targeted treatments in patients with cancer. J. Intern. Med. 2015, 278, 545-570. [CrossRef]

7. Simpson, E.R.; Davis, S.R. Minireview: Aromatase and the regulation of estrogen biosynthesis-Some new perspectives. Endocrinology 2001, 142, 4589-4594. [CrossRef]

8. Miller, W.R. Biological rationale for endocrine therapy in breast cancer. Best Pract. Res. Clin. Endocrinol. Metab. 2004, 18, 1-32. [CrossRef]

9. Chumsri, S.; Howes, T.; Bao, T.; Sabnis, G.; Brodie, A. Aromatase, aromatase inhibitors, and breast cancer. J. Steroid Biochem. Mol. Biol. 2011, 125, 13-22. [CrossRef]

10. Cataliotti, L.; Buzdar, A.U.; Noguchi, S.; Bines, J.; Takatsuka, Y.; Petrakova, K.; Dube, P.; de Oliveira, C.T. Comparison of anastrozole versus tamoxifen as preoperative therapy in postmenopausal women with hormone receptor-positive breast cancer: The Pre-Operative "Arimidex" Compared to Tamoxifen (PROACT) trial. Cancer 2006, 106, 2095-2103. [CrossRef]

11. Choi, H.J.; Lui, A.; Ogony, J.; Jan, R.; Sims, P.J.; Lewis-Wambi, J. Targeting interferon response genes sensitizes aromatase inhibitor resistant breast cancer cells to estrogen-induced cell death. Breast Cancer Res. 2015, 17, 6. [CrossRef] 
12. Cheon, H.; Stark, G.R. Unphosphorylated STAT1 prolongs the expression of interferon-induced immune regulatory genes. Proc. Natl. Acad. Sci. USA 2009, 106, 9373-9378. [CrossRef]

13. Khodarev, N.N.; Roizman, B.; Weichselbaum, R.R. Molecular pathways: Interferon/stat1 pathway: Role in the tumor resistance to genotoxic stress and aggressive growth. Clin. Cancer Res. 2012, 18, 3015-3021. [CrossRef]

14. Kuo, Y.B.; Chan, C.C.; Chang, C.A.; Fan, C.W.; Hung, R.P.; Hung, Y.S.; Chen, K.T.; Yu, J.S.; Chang, Y.S.; Chan, E.C. Identification of phospholipid scramblase 1 as a biomarker and determination of its prognostic value for colorectal cancer. Mol. Med. 2011, 17, 41-47. [CrossRef]

15. Kim, N.H.; Sung, H.Y.; Choi, E.N.; Lyu, D.; Choi, H.J.; Ju, W.; Ahn, J.H. Aberrant DNA methylation in the IFITM1 promoter enhances the metastatic phenotype in an intraperitoneal xenograft model of human ovarian cancer. Oncol. Rep. 2014, 31, 2139-2146. [CrossRef]

16. Li, D.; Peng, Z.; Tang, H.; Wei, P.; Kong, X.; Yan, D.; Huang, F.; Li, Q.; Le, X.; Li, Q.; et al. KLF4-mediated negative regulation of IFITM3 expression plays a critical role in colon cancer pathogenesis. Clin. Cancer Res. 2011, 17, 3558-3568. [CrossRef]

17. Cheon, H.; Holvey-Bates, E.G.; Schoggins, J.W.; Forster, S.; Hertzog, P.; Imanaka, N.; Rice, C.M.; Jackson, M.W.; Junk, D.J.; Stark, G.R. IFNbeta-dependent increases in STAT1, STAT2, and IRF9 mediate resistance to viruses and DNA damage. EMBO J. 2013, 32, 2751-2763. [CrossRef]

18. Rao, X.; Di Leva, G.; Li, M.; Fang, F.; Devlin, C.; Hartman-Frey, C.; Burow, M.E.; Ivan, M.; Croce, C.M.; Nephew, K.P. MicroRNA221/222 confers breast cancer fulvestrant resistance by regulating multiple signaling pathways. Oncogene 2011, 30, $1082-1097$. [CrossRef]

19. Stark, G.R.; Kerr, I.M.; Williams, B.R.; Silverman, R.H.; Schreiber, R.D. How cells respond to interferons. Annu. Rev. Biochem. 1998, 67, 227-264. [CrossRef]

20. Stark, G.R. How cells respond to interferons revisited: From early history to current complexity. Cytokine Growth Factor Rev. 2007, 18, 419-423. [CrossRef]

21. Brass, A.L.; Huang, I.C.; Benita, Y.; John, S.P.; Krishnan, M.N.; Feeley, E.M.; Ryan, B.J.; Weyer, J.L.; van der Weyden, L.; Fikrig, E.; et al. The IFITM proteins mediate cellular resistance to influenza A H1N1 virus, West Nile virus, and dengue virus. Cell 2009, 139, 1243-1254. [CrossRef]

22. Sun, F.; Xia, Z.; Han, Y.; Gao, M.; Wang, L.; Wu, Y.; Sabatier, J.M.; Miao, L.; Cao, Z. Topology, Antiviral Functional Residues and Mechanism of IFITM1. Viruses 2020, 12, 295. [CrossRef]

23. Li, K.; Jia, R.; Li, M.; Zheng, Y.M.; Miao, C.; Yao, Y.; Ji, H.L.; Geng, Y.; Qiao, W.; Albritton, L.M.; et al. A sorting signal suppresses IFITM1 restriction of viral entry. J. Biol. Chem. 2015, 290, 4248-4259. [CrossRef]

24. Prat, A.; Pineda, E.; Adamo, B.; Galvan, P.; Fernandez, A.; Gaba, L.; Diez, M.; Viladot, M.; Arance, A.; Munoz, M. Clinical implications of the intrinsic molecular subtypes of breast cancer. Breast 2015, 24 (Suppl. 2), S26-S35. [CrossRef]

25. Yu, F.; Xie, D.; Ng, S.S.; Lum, C.T.; Cai, M.Y.; Cheung, W.K.; Kung, H.F.; Lin, G.; Wang, X.; Lin, M.C. IFITM1 promotes the metastasis of human colorectal cancer via CAV-1. Cancer Lett. 2015, 368, 135-143. [CrossRef]

26. Lui, A.J.; Geanes, E.S.; Ogony, J.; Behbod, F.; Marquess, J.; Valdez, K.; Jewell, W.; Tawfik, O.; Lewis-Wambi, J. IFITM1 suppression blocks proliferation and invasion of aromatase inhibitor-resistant breast cancer in vivo by JAK/STAT-mediated induction of p21. Cancer Lett. 2017, 399, 29-43. [CrossRef]

27. Sari, I.N.; Yang, Y.G.; Phi, L.T.; Kim, H.; Baek, M.J.; Jeong, D.; Kwon, H.Y. Interferon-induced transmembrane protein 1 (IFITM1) is required for the progression of colorectal cancer. Oncotarget 2016, 7, 86039-86050. [CrossRef]

28. Hatano, H.; Kudo, Y.; Ogawa, I.; Tsunematsu, T.; Kikuchi, A.; Abiko, Y.; Takata, T. IFN-induced transmembrane protein 1 promotes invasion at early stage of head and neck cancer progression. Clin. Cancer Res. 2008, 14, 6097-6105. [CrossRef] [PubMed]

29. He, J.D.; Luo, H.L.; Li, J.; Feng, W.T.; Chen, L.B. Influences of the interferon induced transmembrane protein 1 on the proliferation, invasion, and metastasis of the colorectal cancer SW480 cell lines. Chin. Med. J. 2012, 125, 517-522. [PubMed]

30. Yu, F.; Ng, S.S.; Chow, B.K.; Sze, J.; Lu, G.; Poon, W.S.; Kung, H.F.; Lin, M.C. Knockdown of interferon-induced transmembrane protein 1 (IFITM1) inhibits proliferation, migration, and invasion of glioma cells. J. Neuro-Oncol. 2011, 103, 187-195. [CrossRef] [PubMed]

31. Gyorffy, B.; Dietel, M.; Fekete, T.; Lage, H. A snapshot of microarray-generated gene expression signatures associated with ovarian carcinoma. Int. J. Gynecol. Cancer 2008, 18, 1215-1233. [CrossRef]

32. Seyfried, N.T.; Huysentruyt, L.C.; Atwood, J.A., III; Xia, Q.; Seyfried, T.N.; Orlando, R. Up-regulation of NG2 proteoglycan and interferon-induced transmembrane proteins 1 and 3 in mouse astrocytoma: A membrane proteomics approach. Cancer Lett. 2008, 263, 243-252. [CrossRef]

33. Lee, J.; Goh, S.H.; Song, N.; Hwang, J.A.; Nam, S.; Choi, I.J.; Shin, A.; Kim, I.H.; Ju, M.H.; Jeong, J.S.; et al. Overexpression of IFITM1 has clinicopathologic effects on gastric cancer and is regulated by an epigenetic mechanism. Am. J. Pathol. 2012, 181, 43-52. [CrossRef]

34. Bjornstrom, L.; Sjoberg, M. Mechanisms of estrogen receptor signaling: Convergence of genomic and nongenomic actions on target genes. Mol. Endocrinol. 2005, 19, 833-842. [CrossRef]

35. Bjornstrom, L.; Sjoberg, M. Signal transducers and activators of transcription as downstream targets of nongenomic estrogen receptor actions. Mol. Endocrinol. 2002, 16, 2202-2214. [CrossRef]

36. Kovats, S. Estrogen receptors regulate innate immune cells and signaling pathways. Cell. Immunol. 2015, 294, 63-69. [CrossRef] 
37. Houtman, R.; de Leeuw, R.; Rondaij, M.; Melchers, D.; Verwoerd, D.; Ruijtenbeek, R.; Martens, J.W.; Neefjes, J.; Michalides, R. Serine-305 phosphorylation modulates estrogen receptor alpha binding to a coregulator peptide array, with potential application in predicting responses to tamoxifen. Mol. Cancer Ther. 2012, 11, 805-816. [CrossRef]

38. Le Romancer, M.; Treilleux, I.; Bouchekioua-Bouzaghou, K.; Sentis, S.; Corbo, L. Methylation, a key step for nongenomic estrogen signaling in breast tumors. Steroids 2010, 75, 560-564. [CrossRef]

39. Jiang, S.Y.; Wolf, D.M.; Yingling, J.M.; Chang, C.; Jordan, V.C. An estrogen receptor positive MCF-7 clone that is resistant to antiestrogens and estradiol. Mol. Cell. Endocrinol. 1992, 90, 77-86. [CrossRef]

40. Murphy, C.S.; Pink, J.J.; Jordan, V.C. Characterization of a receptor-negative, hormone-nonresponsive clone derived from a T47D human breast cancer cell line kept under estrogen-free conditions. Cancer Res. 1990, 50, 7285-7292.

41. Keydar, I.; Chen, L.; Karby, S.; Weiss, F.R.; Delarea, J.; Radu, M.; Chaitcik, S.; Brenner, H.J. Establishment and characterization of a cell line of human breast carcinoma origin. Eur. J. Cancer 1979, 15, 659-670. [CrossRef]

42. Escher, T.E.; Lui, A.J.; Geanes, E.S.; Walter, K.R.; Tawfik, O.; Hagan, C.R.; Lewis-Wambi, J. Interaction Between MUC1 and STAT1 Drives IFITM1 Overexpression in Aromatase Inhibitor-Resistant Breast Cancer Cells and Mediates Estrogen-Induced Apoptosis. Mol. Cancer Res. 2019, 17, 1180-1194. [CrossRef]

43. DeMichele, A.M.; Clark, A.S.; Holmes, R.; Volpe, M.; Medrano, C.; Troxel, A.; Fox, K.; Domchek, S.; Matro, J.; Bradbury, A.; et al. Targeting inflammatory pathways: A phase 2 trial of the JAK-inhibitor ruxolitinib in combination with exemestane for aromatase inhibitor-resistant, estrogen receptor-positive breast cancer [abstract]. In Proceedings of the 2016 San Antonio Breast Cancer Symposium, San Antonio, TX, USA, 6-10 December 2016.

44. Ogony, J.; Choi, H.J.; Lui, A.; Cristofanilli, M.; Lewis-Wambi, J. Interferon-induced transmembrane protein 1 (IFITM1) overexpression enhances the aggressive phenotype of SUM149 inflammatory breast cancer cells in a signal transducer and activator of transcription 2 (STAT2)-dependent manner. Breast Cancer Res. 2016, 18, 25. [CrossRef]

45. Chang, T.C.; Wentzel, E.A.; Kent, O.A.; Ramachandran, K.; Mullendore, M.; Lee, K.H.; Feldmann, G.; Yamakuchi, M.; Ferlito, M.; Lowenstein, C.J.; et al. Transactivation of miR-34a by p53 broadly influences gene expression and promotes apoptosis. Mol. Cell 2007, 26, 745-752. [CrossRef]

46. Tovchigrechko, A.; Vakser, I.A. GRAMM-X public web server for protein-protein docking. Nucleic Acids Res. 2006, 34 (Suppl. 2), W310-W314. [CrossRef]

47. Tovchigrechko, A.; Vakser, I.A. Development and testing of an automated approach to protein docking. Proteins 2005, 60, 296-301. [CrossRef]

48. Alexander, N.; Woetzel, N.; Meiler, J. Bcl::Cluster: A method for clustering biological molecules coupled with visualization in the Pymol Molecular Graphics System. In Proceedings of the 2011 IEEE 1st International Conference on Computational Advances in Bio and Medical Sciences (ICCABS), Orlando, FL, USA, 3-5 February 2011; pp. 13-18. [CrossRef]

49. Jordan, V.C.; Lewis-Wambi, J.S.; Patel, R.R.; Kim, H.; Ariazi, E.A. New hypotheses and opportunities in endocrine therapy: Amplification of oestrogen-induced apoptosis. Breast 2009, 18 (Suppl. 3), S10-S17. [CrossRef]

50. Lewis-Wambi, J.S.; Cunliffe, H.E.; Kim, H.R.; Willis, A.L.; Jordan, V.C. Overexpression of CEACAM6 promotes migration and invasion of oestrogen-deprived breast cancer cells. Eur. J. Cancer 2008, 44, 1770-1779. [CrossRef]

51. Lewis, J.S.; Meeke, K.; Osipo, C.; Ross, E.A.; Kidawi, N.; Li, T.; Bell, E.; Chandel, N.S.; Jordan, V.C. Intrinsic mechanism of estradiol-induced apoptosis in breast cancer cells resistant to estrogen deprivation. J. Natl. Cancer Inst. 2005, 97, 1746-1759. [CrossRef]

52. Ma, C.X.; Reinert, T.; Chmielewska, I.; Ellis, M.J. Mechanisms of aromatase inhibitor resistance. Nat. Rev. Cancer 2015, 15, 261-275. [CrossRef]

53. Goldstein, D.; Bushmeyer, S.M.; Witt, P.L.; Jordan, V.C.; Borden, E.C. Effects of type I and II interferons on cultured human breast cells: Interaction with estrogen receptors and with tamoxifen. Cancer Res. 1989, 49, 2698-2702. [PubMed]

54. Barak, V.; Kalickman, I.; Nisman, B.; Farbstein, H.; Fridlender, Z.G.; Baider, L.; Kaplan, A.; Stephanos, S.; Peretz, T. Changes in cytokine production of breast cancer patients treated with interferons. Cytokine 1998, 10, 977-983. [CrossRef] [PubMed]

55. Dimitrov, N.V.; Meyer, C.J.; Strander, H.; Einhorn, S.; Cantell, K. Interferon as a modifier of estrogen receptors. Ann. Clin. Lab. Sci. 1984, 14, 32-39. [PubMed]

56. Van den Berg, H.W.; Leahey, W.J.; Lynch, M.; Clarke, R.; Nelson, J. Recombinant human interferon alpha increases oestrogen receptor expression in human breast cancer cells (ZR-75-1) and sensitizes them to the anti-proliferative effects of tamoxifen. Br. J. Cancer 1987, 55, 255-257. [CrossRef]

57. Bowie, M.L.; Dietze, E.C.; Delrow, J.; Bean, G.R.; Troch, M.M.; Marjoram, R.J.; Seewaldt, V.L. Interferon-regulatory factor-1 is critical for tamoxifen-mediated apoptosis in human mammary epithelial cells. Oncogene 2004, 23, 8743-8755. [CrossRef]

58. Bouker, K.B.; Skaar, T.C.; Fernandez, D.R.; O'Brien, K.A.; Riggins, R.B.; Cao, D.; Clarke, R. interferon regulatory factor-1 mediates the proapoptotic but not cell cycle arrest effects of the steroidal antiestrogen ICI 182,780 (faslodex, fulvestrant). Cancer Res. 2004, 64, 4030-4039. [CrossRef]

59. Gu, Z.; Lee, R.Y.; Skaar, T.C.; Bouker, K.B.; Welch, J.N.; Lu, J.; Liu, A.; Zhu, Y.; Davis, N.; Leonessa, F.; et al. Association of interferon regulatory factor-1, nucleophosmin, nuclear factor-kappaB, and cyclic AMP response element binding with acquired resistance to Faslodex (ICI 182,780). Cancer Res. 2002, 62, 3428-3437.

60. Schwartz, J.L.; Shajahan, A.N.; Clarke, R. The Role of Interferon Regulatory Factor-1 (IRF1) in Overcoming Antiestrogen Resistance in the Treatment of Breast Cancer. Int. J. Breast Cancer 2011, 2011, 912102. [CrossRef] 
61. Coughlan, N.; Thillainadesan, G.; Andrews, J.; Isovic, M.; Torchia, J. $\beta$-Estradiol-dependent activation of the JAK/STAT pathway requires p/CIP and CARM1. Biochim. Biophys. Acta 2013, 1833, 1463-1475. [CrossRef]

62. Laffont, S.; Rouquié, N.; Azar, P.; Seillet, C.; Plumas, J.; Aspord, C.; Guéry, J.-C. X-Chromosome Complement and Estrogen Receptor Signaling Independently Contribute to the Enhanced TLR7-Mediated IFN- $\alpha$ Production of Plasmacytoid Dendritic Cells from Women. J. Immunol. 2014, 193, 5444-5452. [CrossRef]

63. Panchanathan, R.; Shen, H.; Zhang, X.; Ho, S.M.; Choubey, D. Mutually positive regulatory feedback loop between interferons and estrogen receptor-alpha in mice: Implications for sex bias in autoimmunity. PLoS ONE 2010, 5, e10868. [CrossRef]

64. Singh, R.P.; Hahn, B.H. Interferon Genes are Influenced by Sex Hormones (17b-estradiol) in SLE. J. Immunol. 2020, 204 (Suppl. 1).

65. Cervantes-Badillo, M.G.; Paredes-Villa, A.; Gómez-Romero, V.; Cervantes-Roldán, R.; Arias-Romero, L.E.; Villamar-Cruz, O.; González-Montiel, M.; Barrios-García, T.; Cabrera-Quintero, A.J.; Rodríguez-Gómez, G.; et al. IFI27/ISG12 Downregulates Estrogen Receptor $\alpha$ Transactivation by Facilitating Its Interaction With CRM1/XPO1 in Breast Cancer Cells. Front. Endocrinol. 2020, 11, 792. [CrossRef]

66. Hou, Y.; Li, X.; Li, Q.; Xu, J.; Yang, H.; Xue, M.; Niu, G.; Zhuo, S.; Mu, K.; Wu, G.; et al. STAT1 facilitates oestrogen receptor alpha transcription and stimulates breast cancer cell proliferation. J. Cell Mol. Med. 2018, 22, 6077-6086. [CrossRef]

67. Anbalagan, M.; Rowan, B.G. Estrogen receptor alpha phosphorylation and its functional impact in human breast cancer. Mol. Cell. Endocrinol. 2015, 418 Pt 3, 264-272. [CrossRef]

68. Fedele, P.; Calvani, N.; Marino, A.; Orlando, L.; Schiavone, P.; Quaranta, A.; Cinieri, S. Targeted agents to reverse resistance to endocrine therapy in metastatic breast cancer: Where are we now and where are we going? Crit. Rev. Oncol. Hematol. 2012, 84, 243-251. [CrossRef]

69. Rani, A.; Stebbing, J.; Giamas, G.; Murphy, J. Endocrine Resistance in Hormone Receptor Positive Breast Cancer-From Mechanism to Therapy. Front. Endocrinol. 2019, 10, 245. [CrossRef]

70. Fan, P.; Jordan, V.C. New insights into acquired endocrine resistance of breast cancer. Cancer Drug Resist. 2019, 2, 198-209. [CrossRef]

71. Polyak, K. Tumor heterogeneity confounds and illuminates: A case for Darwinian tumor evolution. Nat. Med. 2014, 20, 344-346. [CrossRef]

72. Johnson, M.R.; Valentine, C.; Basilico, C.; Mansukhani, A. FGF signaling activates STAT1 and p21 and inhibits the estrogen response and proliferation of MCF-7 cells. Oncogene 1998, 16, 2647-2656. [CrossRef]

73. Walter, K.R.; Balko, J.M.; Hagan, C.R. Progesterone receptor promotes degradation of STAT2 to inhibit the interferon response in breast cancer. Oncoimmunology 2020, 9, 1758547. [CrossRef] [PubMed]

74. Goodman, M.L.; Trinca, G.M.; Walter, K.R.; Papachristou, E.K.; D'Santos, C.S.; Li, T.; Liu, Q.; Lai, Z.; Chalise, P.; Madan, R.; et al. Progesterone Receptor Attenuates STAT1-Mediated IFN Signaling in Breast Cancer. J. Immunol. 2019, 202, 3076-3086. [CrossRef] [PubMed]

75. Ariazi, E.A.; Ariazi, J.L.; Cordera, F.; Jordan, V.C. Estrogen receptors as therapeutic targets in breast cancer. Curr. Top. Med. Chem. 2006, 6, 181-202. [CrossRef] [PubMed]

76. Lewis, J.S.; Osipo, C.; Meeke, K.; Jordan, V.C. Estrogen-induced apoptosis in a breast cancer model resistant to long-term estrogen withdrawal. J. Steroid Biochem. Mol. Biol. 2005, 94, 131-141. [CrossRef]

77. Pink, J.J.; Jiang, S.Y.; Fritsch, M.; Jordan, V.C. An estrogen-independent MCF-7 breast cancer cell line which contains a novel 80-kilodalton estrogen receptor-related protein. Cancer Res. 1995, 55, 2583-2590.

78. Ellis, M.J.; Gao, F.; Dehdashti, F.; Jeffe, D.B.; Marcom, P.K.; Carey, L.A.; Dickler, M.N.; Silverman, P.; Fleming, G.F.; Kommareddy, A.; et al. Lower-dose vs high-dose oral estradiol therapy of hormone receptor-positive, aromatase inhibitorresistant advanced breast cancer: A phase 2 randomized study. Jama 2009, 302, 774-780. [CrossRef]

79. Iwase, H.; Yamamoto, Y.; Yamamoto-Ibusuki, M.; Murakami, K.I.; Okumura, Y.; Tomita, S.; Inao, T.; Honda, Y.; Omoto, Y.; Iyama, K.I. Ethinylestradiol is beneficial for postmenopausal patients with heavily pre-treated metastatic breast cancer after prior aromatase inhibitor treatment: A prospective study. Br. J. Cancer 2013, 109, 1537-1542. [CrossRef]

80. Beex, L.; Pieters, G.; Smals, A.; Koenders, A.; Benraad, T.; Kloppenborg, P. Tamoxifen versus ethinyl estradiol in the treatment of postmenopausal women with advanced breast cancer. Cancer Treat. Rep. 1981, 65, 179-185.

81. Kota, K.; Brufsky, A.; Oesterreich, S.; Lee, A. Estradiol as a Targeted, Late-Line Therapy in Metastatic Breast Cancer with Estrogen Receptor Amplification. Cureus 2017, 9, e1434. [CrossRef]

82. Chalasani, P.; Stopeck, A.; Clarke, K.; Livingston, R. A pilot study of estradiol followed by exemestane for reversing endocrine resistance in postmenopausal women with hormone receptor-positive metastatic breast cancer. Oncologist 2014, 19, 1127-1128. [CrossRef]

83. Dunbier, A.K.; Ghazoui, Z.; Anderson, H.; Salter, J.; Nerurkar, A.; Osin, P.; A'Hern, R.; Miller, W.R.; Smith, I.E.; Dowsett, M. Molecular profiling of aromatase inhibitor-treated postmenopausal breast tumors identifies immune-related correlates of resistance. Clin. Cancer Res. 2013, 19, 2775-2786. [CrossRef] 